\title{
Modeling suspended sediment discharge from the Waipaoa River system, New Zealand: The last 3000 years
}

\author{
A. J. Kettner, ${ }^{1,2}$ B. Gomez, ${ }^{3}$ and J. P. M. Syvitski ${ }^{1}$ \\ Received 27 September 2006; revised 28 February 2007; accepted 14 March 2007; published 12 July 2007.
}

[1] HydroTrend, a hydrologic-transport model, is used to simulate the water and suspended sediment discharge of the Waipaoa River system over the last $3 \mathrm{Kyr}$, a time period in which a well-documented sequence of natural events and anthropogenic activities that profoundly impacted drainage basin processes occurred. Comparisons between observed and simulated data show that the model output replicates the frequency and distribution of flow events and the suspended sediment concentration-discharge relationship, and the long-term trends in suspended sediment discharge are consistent with the sediment record preserved on the middle shelf. Water discharge tracks precipitation, and average annual discharge may have been up to $20 \%$ higher and $6 \%$ lower at different times in the past. Suspended sediment discharge changed from $2.3 \pm 4.5$ to $14.9 \pm 8.7 \mathrm{Mt} \mathrm{yr}^{-1}$ during the Anthropocene, increasing by $140 \%$ after Polynesian arrival, by $350 \%$ after European colonization, and by $660 \%$ after the catchment headwaters were deforested.

Citation: Kettner, A. J., B. Gomez, and J. P. M. Syvitski (2007), Modeling suspended sediment discharge from the Waipaoa River system, New Zealand: The last 3000 years, Water Resour. Res., 43, W07411, doi:10.1029/2006WR005570.

\section{Introduction}

[2] The sediment flux from rivers to Earth's oceans has been shown to vary over time in response to changes in catchment conditions that regulate the sediment supply from uplands, and transport and storage within channels [Blum and Törnqvist, 2000; Veldkamp and Tebbens, 2001; Phillips, 2003; Walling and Fang, 2003; Meybeck and Vörösmarty, 2005; Syvitski et al., 2005]. Conversely, sediment fluxes may remain relatively constant because the influence of one controlling factor predominates [Summerfield and Hulton, 1994; Gunnell, 1998], or because variations in the sediment supply are masked by the movement of sediment into and out of storage [Métivier and Gaudemar, 1999; Phillips, 2003]. Isolating the factors that influence the response of river-sediment discharge is important both for evaluating catchment sensitivity to environmental change, and the effect it has on the land-ocean transfer of terrigenous sediment and associated bio-limiting nutrients [Syvitski and Morehead, 1999; Sommerfield et al., 2002; Gomez et al., 2003; Leithold et al., 2005]. However, this is difficult to accomplish because high resolution, time-varying records of sediment delivery to the ocean are available for $<10 \%$ of Earth's rivers [Syvitski et al., 2005]; the available instrumental records usually are not long enough to resolve the cause(s) of changes in catchment sediment yields [Wilby

\footnotetext{
${ }^{1}$ Environmental Computation and Imaging Group, Institute of Arctic and Alpine Research (INSTAAR), University of Colorado, Boulder, Colorado, USA.

${ }^{2}$ Section of Applied Geology, Faculty of Civil Engineering and Geosciences, Delft University of Technology, Delft, Netherlands.

${ }^{3}$ Geomorphology Laboratory, Indiana State University, Terre Haute, Indiana, USA.

Copyright 2007 by the American Geophysical Union. 0043-1397/07/2006WR005570\$09.00
}

et al., 1997]; and proxy data are rarely able to elucidate the recurrence intervals or intensities of individual events [Gomez et al., 2002; Noren et al., 2002]. An alternative approach to investigating the nature of a river's water and sediment discharge over long periods of time is to use a numerical model to create synthetic time series [Syvitski and Morehead, 1999; Morehead et al., 2003; Kettner and Syvitski, HydroTrend version 3.0: A climate-driven hydrological transport model that simulates discharge and sediment load leaving a river system, submitted to Computers and Geosciences, 2007, hereinafter referred to as Kettner and Syvitski, submitted manuscript, 2007].

[3] HydroTrend is a climate-driven hydrologic-transport model which creates water and suspended-sediment discharge time series as a function of climate and local catchment characteristics that influence the hydrology of the contributing rivers [Mulder and Syvitski, 1996]. The model has been validated with data from the Eel River, a steepland river system that drains the California-OregonWashington continental margin [Syvitski et al., 1998; Syvitski and Morehead, 1999]. Elevated suspended sediment concentrations occur in many steepland rivers because of the high erodibility of the adjacent land surface, which is a product of tectonics, climate, and human interference [Wang et al., 1997; Scott et al., 2006]. Accordingly, a large percentage of their sediment (and, by association, biolimiting nutrient) load is conveyed directly to Earth's oceans [Milliman and Syvitski, 1992; Lyons et al., 2002]. Herein HydroTrend is employed to reproduce the water and suspended sediment discharge time series of the Waipaoa River system over the past $3 \mathrm{Kyr}$, and the model output is used to assess the relative impact of different categories of late Holocene environmental change on river-sediment discharge. The Waipaoa River system is one of three highyield, mesoscale river systems draining the northern sector 


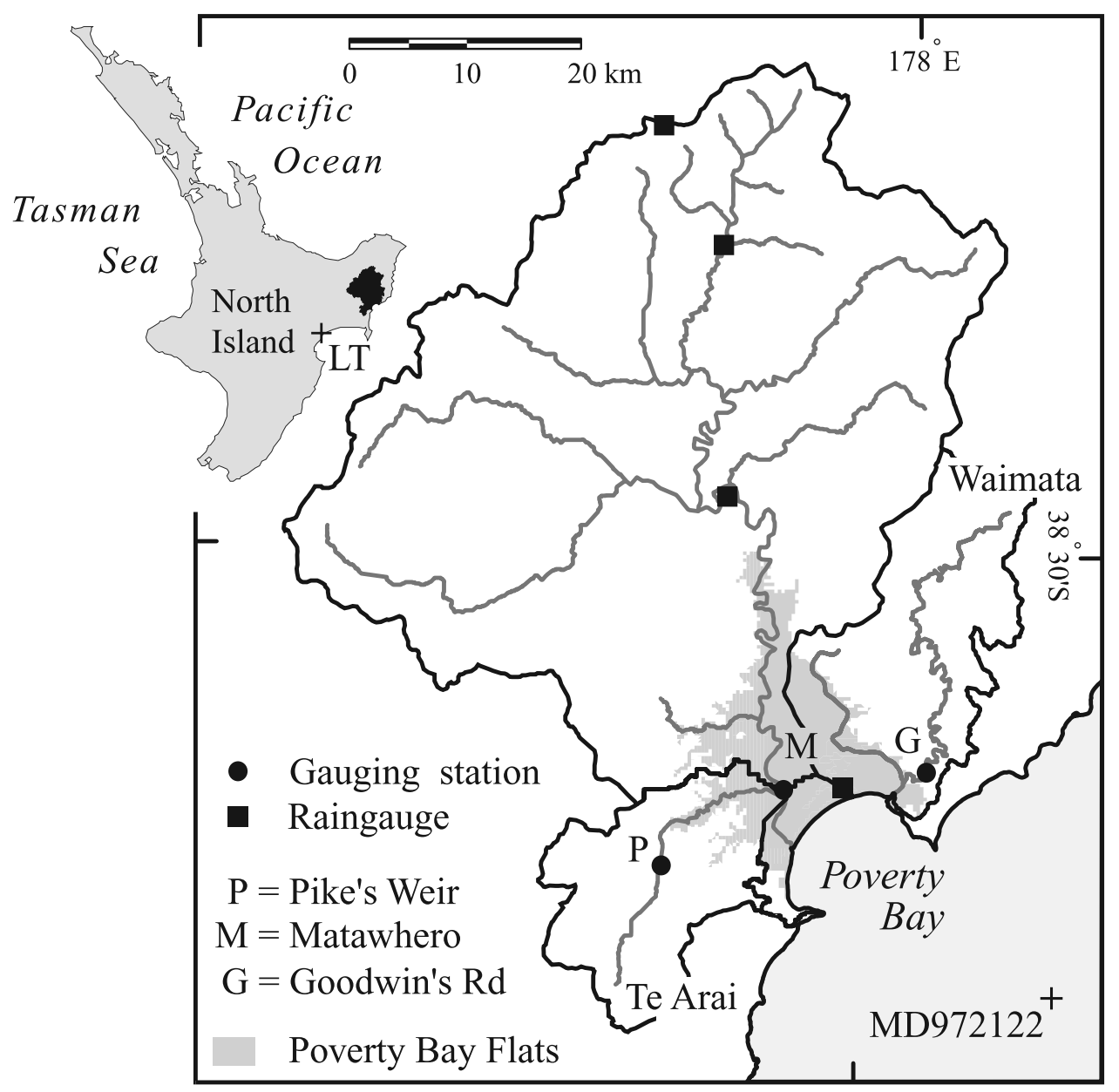

Figure 1. Location map showing gauging station and rain gauge sites in the Waipaoa, Te Arai, and Waimata catchments. On the inset map LT indicates the location of Lake Tutira.

of the East Coast Continental Margin, North Island, New Zealand, that collectively generate $\sim 0.3 \%$ of the global suspended sediment input to the ocean from only $\sim 0.003 \%$ of Earth's total land area [Hicks et al., 2004]. The time period in question encompasses a well-documented sequence of natural events and anthropogenic activities that profoundly impacted drainage basin processes [Gomez et al., 2007; Phillips and Gomez, 2007], and provide a background for interpreting the sensitivity of sediment fluxes to changes in the catchment environment and the behavior of the Waipaoa River system's hydrological regime in the past. The river system has also been the subject of hydrogeomorphological investigations for over half a century, climatological records extend back to the early years of the twentieth century, hydrological records have been maintained since 1960, and there is a rich record of late Holocene environmental change preserved in sedimentary deposits contained in lakes, on floodplains, and on the continental shelf [Waipaoa Catchment Study Project Team, 1994; Wilmshurst et al., 1999; Gomez et al., 2004a, 2007]. These sources provide a robust foundation for the present investigation and the available data help compensate for the many unknown contingencies that attempts to generate water discharge and sediment load records for river basins commonly encounter [cf. Syvitski and Morehead, 1999].

\section{The Waipaoa River System}

[4] The Waipaoa River discharges water and sediment to the north-central sector of the tectonically active East Coast Continental Margin, North Island, New Zealand (Figure 1), and 1718 calendar years B.P. the catchment was blanketed by ash from the violent and explosive Taupo eruption [Wilson and Walker, 1985; Berryman et al., 1989]. Sea level on the East Coast Continental Margin has not changed appreciably during the past $3 \mathrm{Kyr}$, but the Poverty Bay Flats have prograded, and the rate of subduction-related uplift in the headwaters of the Waipaoa River basin is $\sim 4 \mathrm{~mm} \mathrm{yr}^{-1}$ [Brown, 1995; Berryman et al., 2000; Carter et al., 2002]. Herein reference is made to the Waipaoa River system, which at different periods in the last $3 \mathrm{Kyr}$ encompassed the $1987 \mathrm{~km}^{2}$ and/or the 216 and $312 \mathrm{~km}^{2}$ Waipaoa, Te Arai, and Waimata catchments. This is because at some point after the Taupo eruption the Waipaoa captured the Te Arai River and the Waimata drainage was abandoned as the river's lower reaches migrated southward across the Poverty Bay Flats [Pullar and Penahle, 1970]. Summary information about the three catchments is provided in Table 1. 
Table 1. Summary Information on Catchments in the Waipaoa River System, Flows, and Suspended Sediment

\begin{tabular}{|c|c|c|c|}
\hline & Waipaoa & Te Arai & Waimata \\
\hline Area, $\mathrm{km}^{2}$ & 1987 & 216 & 312 \\
\hline Relief, m & 1190 & 685 & 400 \\
\hline $\begin{array}{l}\text { Exploitable rainfall record } \\
\text { at each station, yrs }\end{array}$ & $78,73,21,11$ & 78,11 & 78,9 \\
\hline Mean annual precipitation, $\mathrm{mm}^{\mathrm{b}}$ & 1590 & 1120 & 1160 \\
\hline Mean annual temperature, ${ }^{\circ} \mathrm{C}^{\mathrm{b}}$ & 11.8 & 12.8 & 13.0 \\
\hline Length of flow record, yrs & $46^{\mathrm{a}}$ & 21 & 26 \\
\hline Mean flow, $\mathrm{m}^{3} \mathrm{~s}^{-1}$ & 48.4 & 5.4 & 5.0 \\
\hline Peak flow, $\mathrm{m}^{3} \mathrm{~s}^{-1}$ & 4200 & 380 & 690 \\
\hline $\begin{array}{l}\text { Length of suspended sediment } \\
\text { record, yrs }\end{array}$ & $39^{\mathrm{a}}$ & 23 & 25 \\
\hline $\begin{array}{l}\text { Number of suspended sediment } \\
\text { observations }\end{array}$ & 114 & 66 & 156 \\
\hline $\begin{array}{l}\text { Peak suspended sediment } \\
\text { discharge }\left(\mathrm{kg} \mathrm{s}^{-1}\right)\end{array}$ & 58,157 & 2293 & 3592 \\
\hline At a discharge of, $\mathrm{m}^{3} \mathrm{~s}^{-1}$ & 1986 & 110 & 439 \\
\hline $\begin{array}{l}\text { Mean annual suspended sediment } \\
\text { load, } \mathrm{Mt}^{\mathrm{c}}\end{array}$ & $13.4 \pm 7.3$ & $1.6 \pm 1.0$ & $0.8 \pm 0.7$ \\
\hline
\end{tabular}

${ }^{\mathrm{a}}$ The gauging station at Matawhero is located $1.5 \mathrm{~km}$ downstream from the tidal limit in the Waipaoa River, but neither tidal effects nor wave action have an appreciable influence on the gauging record.

${ }^{\mathrm{b}}$ Basin-wide average.

${ }^{\mathrm{c}}$ Estimated using HydroTrend.

[5] Cretaceous and early Tertiary sedimentary rocks underlie the three catchments, which experience a temperate maritime climate with a mean annual temperature of $14.3^{\circ} \mathrm{C}$ [Hessell, 1980; Mazengarb and Speden, 2000]. Mean annual precipitation is $\sim 1590 \mathrm{~mm}$, ranging from $\sim 1000 \mathrm{~mm}$ at the coast to $\sim 3000 \mathrm{~mm}$ in the headwaters, where the maximum elevation is $1190 \mathrm{~m}$. One or two cyclonic storms normally pass within $100 \mathrm{~km}$ of New Zealand every year, and these events can generate as much as $800 \mathrm{~mm}$ of precipitation in a $72 \mathrm{hr}$ period [Hastings, 1990; Reid and Page, 2002]. Palaeoreconstructions of austral temperatures are incomplete, but there appear to have been only minor changes to the climate of the East Coast region as a whole during the last $3 \mathrm{Kyr}$ [McGlone et al., 1992; Salinger and Mullen, 1999]. However, proxy data obtained from nearby Lake Tutira indicate storm activity varied appreciably during the last $2.25 \mathrm{Kyr}$ [Eden and Page, 1998]. Periodic shifts in the El Niño-Southern Oscillation (ENSO) dominated climate regime may be caused by changes in the zonal westerly airflow and the regional pattern of atmospheric circulation, and those periods when the interval between large storms increases have been linked with drier conditions overall [Burrows and Greenland, 1979; Wilmshurst et al., 1997; Salinger and Mullen, 1999; Shulmeister et al., 2004].

[6] The primary forests in the headwaters and on the Poverty Bay Flats were established in the mid-Holocene [McGlone et al., 1993]. Prior to the arrival of Polynesian settlers the indigenous vegetation was periodically disturbed by volcanic eruptions, fire, and severe storms [Grant, 1989; Wilmshurst et al., 1999]. Cultural activities impacted the vegetation cover from the thirteenth century A.D. onwards, and the wholesale destruction of the forest cover began after the arrival of European colonists in the eighteenth century A.D. [Pullar, 1962; Wilmshurst et al., 1999]. Conversions of land in the headwaters to pasture accelerated in the period from 1890 to 1910 and continued until 1920. Today little of the indigenous vegetation cover remains and $77 \%$ of the land is under pasture. Exotic reforestation of severely eroded land in the headwaters began in 1960, but erosion in the largest gully complexes and fine-sediment production continue apace [Derose et al., 1998; Marden et al., 2005].

[7] Deforestation of the headwaters caused severe hillslope erosion [Gage and Black, 1979], and gully erosion supplemented by shallow landsliding during intense rainstorms currently generates large quantities of fine sediment. In the Waipaoa catchment, gully erosion regulates suspended sediment transport across the entire range of flows, and sustains the very high mean annual suspended sediment discharge of $15.0 \pm 6.7$ Mt [Hicks et al., 2000, 2004]. Shallow landsliding is the dominant erosion process in the Te Arai and Waimata catchments, where there is a threshold effect on sediment availability that gives rise to pronounced (extending over several orders of magnitude) variations in suspended sediment concentration for a given water discharge and lower overall concentrations in the low to moderate flow range [Hicks et al., 2000]. Prior to deforestation there are thought to have been few active gullies in the headwaters, but extensive erosion is known to occur under the native forest cover [Liébault et al., 2005], and although less of the land area would have been susceptible to landsliding it would likely have been the dominant erosion process on steep, riparian hillslopes in all three catchments at that time [Gomez et al., 2004a and 2004b].

\section{The Hydrological Model}

[8] HydroTrend is able to compute water and suspendedsediment discharges in daily increments over very long periods of time (centuries to millennia) using primitive information about the catchment environment, and the simulated data have comparable accuracy to most field observations [Syvitski et al., 2003]. The information required is the representative mean monthly and annual temperature and precipitation and their standard deviation, and basin characteristics and hypsometry [Syvitski et al., 1998; Kettner and Syvitski, submitted manuscript, 2007]. The physical characteristics of the Waipaoa, Te Arai, and Waimata catchments were derived from a 25-m DEM generated using Land Information New Zealand (LINZ) 20-m contours from the 1:50,000 topographic database. Daily data, weighted by elevation, from four climatological stations with between 9 and 78 years of exploitable record were used to compute the mean monthly and mean annual precipitation and their standard deviation for each basin (Figure 1 and Table 1). Using data from the climatological station located $5 \mathrm{~m}$ above sea level, the mean monthly and mean annual temperature and their standard deviation were interpolated on the basis of each basin's lapse rate and hypsometry.

[9] Kettner and Syvitski [2007] demonstrated that, although other formulations may have a better fit to the observed data, an empirical expression that relates the suspended sediment load to (water) discharge, relief, and temperature is better suited to long-term simulations that involve precipitation changes. In this version of HydroTrend, climate and land use change can be accounted for by varying precipitation and/or temperature and the amount of discharge lost to evapotranspiration over time and, although precipitation is distributed evenly across the basin, the shape of the flood hydrograph depends 
on the movement of water into and out of the groundwater reservoir. The variability of suspended sediment concentrations due to shallow landsliding and transmission losses to the floodplain may also be replicated by adjusting the rating curve at specified threshold discharges. Descriptions of HydroTrend's structure and its constituent modules are provided by Syvitski et al. [1998] and Kettner and Syvitski (submitted manuscript, 2007) and are not reiterated here. However, adjustments made to the governing equations for the purposes of this study and boundary conditions imposed on the basis of site-specific hydroclimatological parameters are summarized below.

\subsection{Governing Equations}

[10] HydroTrend computes discharge $Q_{[i]}\left(\mathrm{m}^{3} \mathrm{~s}^{-1}\right)$ using a water balance approach:

$$
Q_{[i]}=Q_{\mathrm{r}[i]} \pm Q_{\mathrm{gr}[i]},-Q_{\text {evap }[i]}
$$

where $Q_{\mathrm{r}}$ is the discharge generated by rain, $Q_{\mathrm{gr}}$ is the groundwater discharge, $Q_{\text {evap }}$ is the amount of discharge lost by evapotranspiration (canopy evaporation and evaporation from the groundwater pool), and the subscript $i$ denotes a daily time step. Depending on the assumed catchment saturated hydraulic conductivity, groundwater discharge lags water discharge by a prescribed number of days; water infiltrates into the groundwater pool until a maximum storage level is attained, and either evaporates or flows back to the river at a constant rate until a minimum storage level is reached [Syvitski et al., 1998]. The percentage of the precipitation reaching the ground as snowfall and its rate of accumulation and melting may also be computed. However, in the context of the temperate climate and moderate elevation of the study area these terms are not significant components of the water balance and, accordingly, are not specified in equation (1).

[11] As is often the case [Ferguson, 1987; Crawford, 1991; Asselman, 2000; Syvitski et al., 2000], suspended sediment concentrations $\left(C_{\mathrm{s}}\right)$ and loads $\left(Q_{\mathrm{s}}\right)$, are determined using an empirical rating relation that has a simple power form when concurrent measurements of $C_{\mathrm{s}}$ and discharge $(Q)$ are plotted on a log-log graph:

$$
C_{\mathrm{s}}=a Q^{b}
$$

or

$$
Q_{\mathrm{s}}=C_{s} Q=a Q^{1+b}
$$

where $a$ and $b$ are empirical coefficients (the $y$ axis intercept and slope of the log-log plot, respectively). However, power law formulations do not have universal applicability, and other statistical models may be better suited to situations where variations in the rate at which sediment is produced and delivered to stream channels impart curvature to the log (discharge)-log (concentration) relation [Hovius et al., 2000; Horowitz, 2003; Hicks and Gomez, 2003]. Nor is hysteresis that imparts variability (scatter) to the relationship between suspended sediment concentration and discharge preserved (Figure 2a). Moreover, although models that account for hysteresis may be used to simulate specific storm events or suspended sediment fluxes over short time intervals they are not applicable to longer timescales [Morehead et al., 2003], when the relation between suspended sediment concentra-
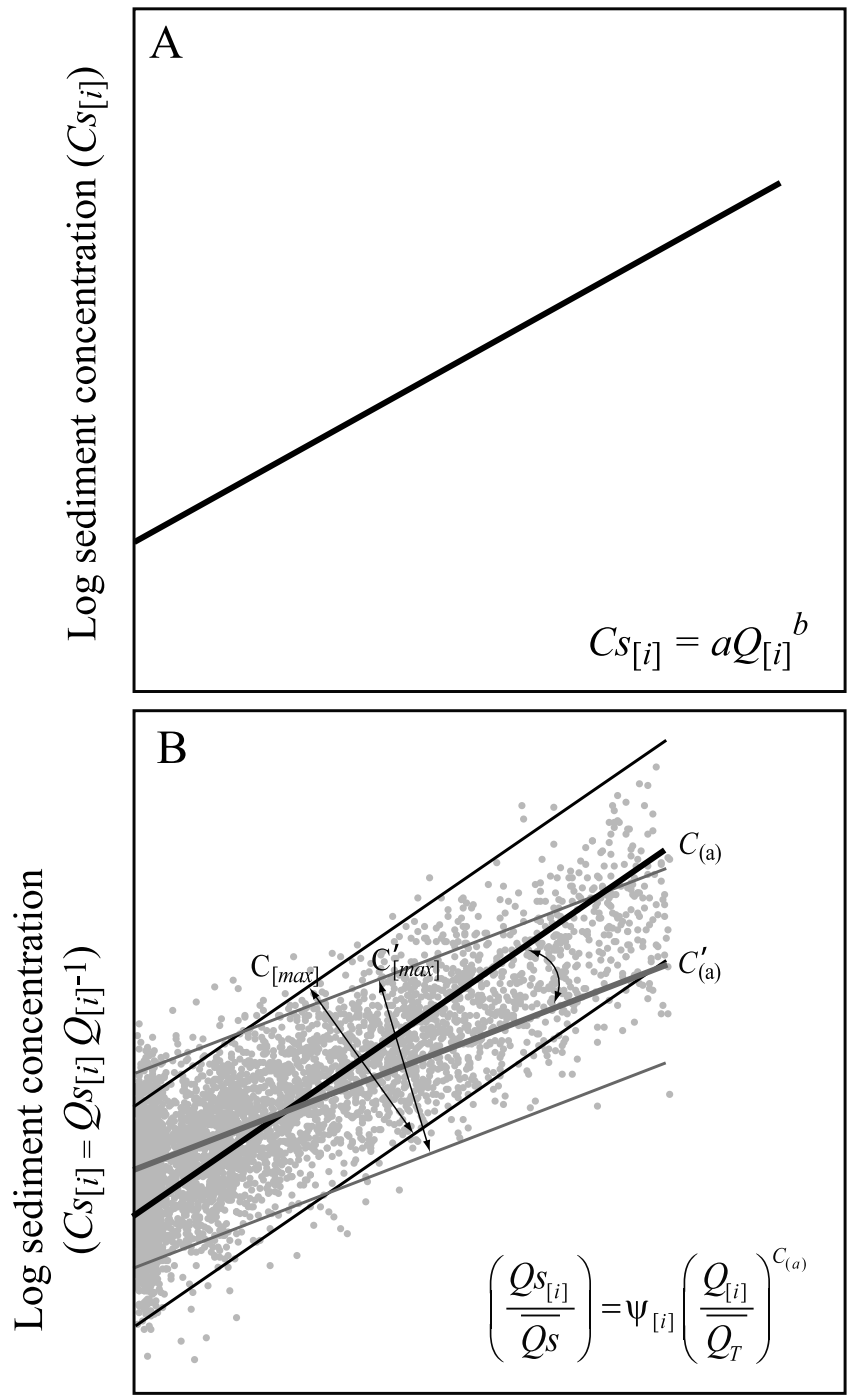

Log water discharge $\left(Q_{[i]}\right)$

Figure 2. Schematic representations of (a) the power law relation $\left(C_{\mathrm{s}}=a Q^{b}\right)$ between $\log$ suspended sediment concentration and log water discharge; and (b) the psi $(\Psi)$ equation embedded in HydroTrend. In the latter plot gray dots represent simulated values, the thick lines illustrate the rating curve for a given year, and the thin lines the upper and lower boundaries between which the suspended sediment concentration $\left(C_{\mathrm{s}}\right)$ can fluctuate (note that at a given discharge HydroTrend is able to generate multiple values of $C_{\mathrm{s}}$ ).

tion and discharge may also be affected by climate change and tectonic activity. To obviate the former effect an upper boundary condition was imposed on the suspended sediment concentration, as specified below, while (intra- and interannual) variability in the relation between suspended sediment concentration and discharge was reproduced by the stochastic relation Morehead et al. [2003] developed:

$$
\left(\frac{Q_{\mathrm{s}_{[i]}}}{\overline{Q_{\mathrm{s}}}}\right)=\psi_{[i]}\left(\frac{Q_{[i]}}{\overline{Q_{T}}}\right)^{C_{(\mathrm{a})}}
$$

where $Q_{\mathrm{s}_{[i]}}$ is the daily simulated suspended sediment load $\left(\mathrm{kg} \mathrm{s}^{-1}\right) ; \overline{Q_{\mathrm{s}}}$ is the long-term average suspended 
sediment load $\left(\mathrm{kg} \mathrm{s}^{-1}\right)$ with the same time period as $\overline{Q_{T}}$, the long-term average discharge $\left(\mathrm{m}^{3} \mathrm{~s}^{-1}\right) ; Q_{[\mathrm{i}]}$ is the daily discharge $\left(\mathrm{m}^{3} \mathrm{~s}^{-1}\right) ; \Psi_{[i]}$ is a (daily) lognormal random distribution; and $C_{(a)}$ is a normally distributed annual rating exponent [Syvitski et al., 2000], with:

$$
\begin{gathered}
\operatorname{mean}(\psi)=1 \\
\text { standard deviation }(\psi)=0.763(0.99995)^{\bar{Q}}
\end{gathered}
$$

and

$$
\text { mean }(C)=1.4-0.025 \bar{T}+0.00013 R+0.145 \ln \left(\overline{Q_{\mathrm{s}}}\right)
$$

standard deviation $(C)=s=0.17+0.0000183 \bar{Q}$

[12] In general, small rivers tend to have more intraannual variability in the sediment flux than large rivers, whereas there is less inter-annual variability in the solids discharge of small rivers than in their larger counterparts [Meybeck et al., 2003; Morehead et al., 2003]. These tendencies are accounted for by equations (6) and (8), respectively, and the overall nature of the variability encapsulated in equations (5)-(8) is illustrated in Figure $2 b$.

[13] As noted in section 1, a plethora of environmental variables affect fluvial sediment fluxes to the ocean, which commonly are encapsulated in empirical relations that relate the suspended sediment load to a surrogate, such as water discharge [for example, equation (3)]. To better represent the governing variables, Mulder and Syvitski [1996] developed a multiparameter correlation between drainage basin area, relief and the long-term sediment load that, with subsequent refinements, permits sediment loads to be predicted to an accuracy of $96 \%$ [Syvitski and Milliman, 2007]. HydroTrend computes the long-term average suspended sediment load $\overline{Q_{\mathrm{s}}}\left(\mathrm{kg} \mathrm{s}^{-1}\right)$, for time periods with constant climate and basin boundary conditions, using a modified version of the empirical relation developed by Syvitski et al. [2003]:

$$
\overline{Q_{\mathrm{s}}}=(\operatorname{veg}) \alpha_{6}{\widehat{Q_{T}}}^{\alpha_{7}} \hat{R}^{\alpha_{8}} e^{k_{2} \hat{T}}
$$

where the nondimensional basin relief, $\hat{R}=\left(\frac{R}{R_{0}}\right)$ with $R_{0} \equiv$ $1 \mathrm{~m}$; the nondimensional water discharge, $\widehat{Q_{T}}=\left(\frac{\overline{Q_{T}}}{Q_{0}}\right)$ with $Q_{0} \equiv 1 \mathrm{~m}^{3} \mathrm{~s}^{-1}$; the coefficient of proportionality for this climatic zone, $\alpha_{6}=0.0011 \mathrm{~kg} \mathrm{~s}^{-1}$; the dimensionless parameters for this climate zone, $\alpha_{7}=0.53, \alpha_{8}=1.1$, and $k_{2}=0.06$; where the nondimensional average basin temperature, $\hat{T}=\left(\frac{\bar{T}}{T_{0}}\right)$ with $\bar{T}=1{ }^{\circ} \mathrm{C}$; and veg is a dimensionless vegetation-erosion index that is equivalent to the term Syvitski and Milliman [2007] used characterize catchment geology, and accounts for the effect changes to the vegetation cover have on erosion rates and sediment production from highly erodible lithologies [cf. Kelsey, 1980; Trustrum et al., 1999; Reid and Page, 2002; Marden et al., 2005].

\subsection{Site-Specific Boundary Conditions}

[14] In the Waipaoa River the rate at which suspended sediment concentration increases declines at higher dis- charges, and the discharge-concentration relation is curved in log-log space [Hicks et al., 2000, 2004]. The highest observed suspended sediment concentration in any New Zealand river is $77 \mathrm{~kg} \mathrm{~m}^{-3}$, in the Waipaoa River it is $36.8 \mathrm{~kg} \mathrm{~m}^{-3}$ (discharge $30 \%$ bankfull), and in both the Te Arai and the Waimata rivers it is $<25.0 \mathrm{~kg} \mathrm{~m}^{-3}$. To avoid inflating the suspended sediment load an upper boundary condition of 60 and $25 \mathrm{~kg} \mathrm{~m}^{-3}$ was imposed on the suspended sediment concentration in the Waipaoa River and the Te Arai and Waimata rivers, respectively. Floodplain storage currently accounts for $16 \%$ of the suspended sediment load of the Waipaoa River transported during events that exceed the reach-average bankfull discharge of $\sim 1506 \pm 408 \mathrm{~m}^{3} \mathrm{~s}^{-1}$ [Gomez et al., 1999, 2006]. Sediment losses due to bar formation in the vicinity of the river mouth and accretion in the coastal zone are not considered herein, but transmission losses to the Poverty Bay Flats were accounted for by making a proportionate reduction in the suspended sediment load at the river mouth whenever the simulated discharge of the Waipaoa River exceeded $1550 \mathrm{~m}^{3} \mathrm{~s}^{-1}$. This sediment was lost to storage for the entire duration of the model run, which is not an unreasonable assumption given that the half-life of Holocene alluvium on Poverty Bay Flats is $>2 \mathrm{Kyr}$ and most losses are due to burial by younger sediment rather than remobilization [Phillips et al., 2007].

[15] Hillslopes become unstable once the precipitation intensity exceeds the threshold for landsliding [Reid and Page, 2002; Jakob and Weatherly, 2003; Gabet et al., 2004], and for a given discharge a higher suspended sediment concentration is observed in catchments, such as the Te Arai and Waimata, where landsliding is the dominant erosion process than in catchments where it is a subordinate process [Fuller et al., 2003; Hicks et al., 2004; Kasai et al., 2001]. The hydroclimatic threshold for landsliding was determined by trial-and-error to be half the mean discharge (Table 1), and at flows in excess of this value the best fit to the suspended sediment ratings for the Te Arai River (in which a threshold on sediment availability is imposed by shallow landsliding [Hicks et al., 2000, 2004]) was obtained when the rating curve exponent was multiplied by a factor of 1.8. This correction was also applied to the Waipaoa River in the period prior to European settlement, when landsliding on riparian hillslopes in the headwaters, not gully erosion, appears to have been the dominant erosion process [Gomez et al., 2004a, 2004b]. Moreover, in this context, it helps to account for the impact air fall tephra, which is an important component of the soil cover on hillslopes throughout the East Coast region [Jessen et al., 1999], has on suspended sediment discharge.

[16] The area of land covered by three vegetation classes (native/exotic forest, secondary forest/scrub, and pasture/ cropland/bare ground) was determined from a Landsat TM image acquired in 1993 [Waipaoa Catchment Study Project Team, 1994], and Pearce et al.'s [1987] estimates of annual total evapotranspiration from forest and pasture in the headwaters of the Waipaoa River basin were used to derive representative values for the amount of discharge lost by evapotranspiration. Changes to the vegetation cover affect both evapotranspiration and sediment production, and basin scale disruptions to the native vegetation are known to have occurred following the Taupo eruption, the arrival of 
Table 2. Variation of Evapotranspiration and Vegetation-Erosion Indices With Vegetation Type

\begin{tabular}{lcc}
\hline \multicolumn{1}{c}{ Vegetation type } & Evapotranspiration $^{\mathrm{a}}$ & Vegetation-Erosion $^{\mathrm{b}}$ \\
\hline Indigenous Forest & 0.67 & 1 \\
Scrub/Secondary Forest & 0.58 & 2 \\
Pasture/Bare Ground/Crops & 0.49 & 10 \\
\hline
\end{tabular}

${ }^{a}$ After Pearce et al. [1987].

${ }^{\mathrm{b}}$ After Page and Trustrum [1997].

humans, the arrival of European settlers, and the subsequent deforestation of the headwaters [Murton, 1968; McGlone, 1989; Wilmshurst et al., 1999]. These disruptions, and that projected to have occurred following the 2120 calendar years B.P. Mapara eruption, were characterized in the model runs as variations in the percentage of land covered by each vegetation class, and the local estimates of evapotranspiration losses by Pearce et al. [1987] and the proxy record of paleolandslide activity from Lake Tutira by Page and Trustrum [1997] were used as a basis for quantifying their effect on evapotranspiration and the vegetation-erosion index, respectively (Table 2 ). We made no attempt to account for the effect earthquakes have on erosion processes, because only qualitative assessments of their impact are available [cf. Guthrie-Smith, 1969; Campbell, 1966].

[17] To account for the observed variations in large, landslide-inducing storms, the proxy record by Eden and Page [1998] was extended using data obtained from a new drill core site in Lake Tutira (M. J. Page, personal communication). The resulting $3 \mathrm{Kyr}$ long-time series was smoothed using a five-point running mean. The average interval between geomorphologically effective storms was extracted, normalized to present-day values and used as a forcing factor to drive precipitation variations during the model runs (Figure 9a). In the absence of more detailed information about the precipitation regime, the magnitude of the forcing factor (equivalent to $\pm 10 \%$ of mean annual precipitation) was determined on the basis of the significant annual rainfall trends that have been identified in the instrumental record [cf. Salinger and Mullen, 1999]. Mean monthly and mean annual temperatures were kept constant during each model run. Catchment relief was also kept constant, because adjustments due to uplift changed the value of this parameter by $<1 \%$. Adjustments to the drainage network are known to have occurred in the period immediately after the Taupo eruption [Pullar and Penahle, 1970], and in the absence of a definitive date for the separation of the Waimata from the Waipaoa River and the capture of the Te Arai River, a date of 1718 calendar years B.P. was assigned to these events. Accordingly, at this time the catchment area decreased from 2299 to $2203 \mathrm{~km}^{2}$. Additional adjustments to catchment area were deemed unnecessary because subsequent progradation of the Poverty Bay Flats changed basin area by only $\sim 1 \%$.

[18] In summary, the contemporary hydroclimatological and hydrogeomorphological regimes defined the boundary conditions for the postdeforestation period. With only a minor $(\sim 4 \%)$ variation in basin area, keeping relief constant, and informed by the observed erosional response to changes in land use, vegetation type or climatic regime, changes to the catchment environment that occurred prior to deforestation were replicated by making proportional adjustments to the vegetation-erosion index, the amount of discharge lost by evapotranspiration and precipitation.

\section{Model Performance}

[19] To evaluate the performance of the model under contemporary conditions, simulated data, corrected by area, are compared with observed data collected at the Matawhero, Pike's Weir and Goodwin's Road gauging stations (Figure 1). In so doing, we reiterate that HydroTrend computes water and suspended-sediment discharges from statistics of monthly and annual temperature and precipitation, basin relief, area and hypsometry [Syvitski et al., 1998; Kettner and Syvitski, submitted manuscript, 2007], and only slight modifications were made to the governing equations by: (1) incorporating a vegetation-erosion index in the model to account for the effect changes in vegetation cover have on sediment production from highly erodible lithologies; (2) using variable, site-specific values for the evapotranspiration coefficient; and (3) accounting for the effect landsliding and transmission losses to the floodplain have on suspended sediment discharge.

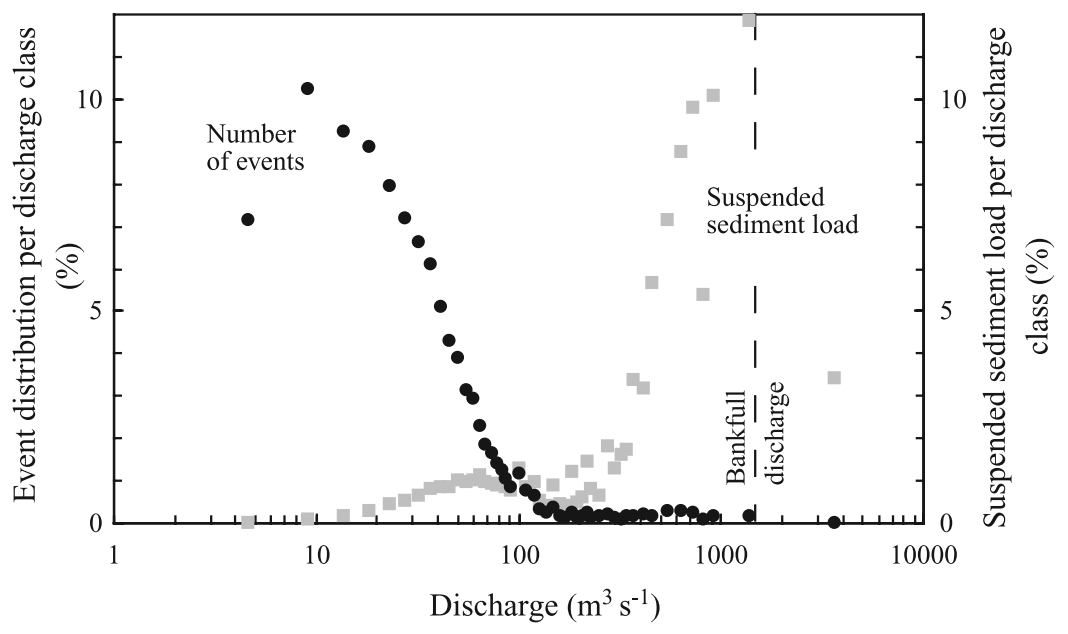

Figure 3. Event distribution and suspended sediment load for specified discharge classes computed from a 25-year time series of daily simulations for the Waipaoa River at Matawhero.

6 of 15 

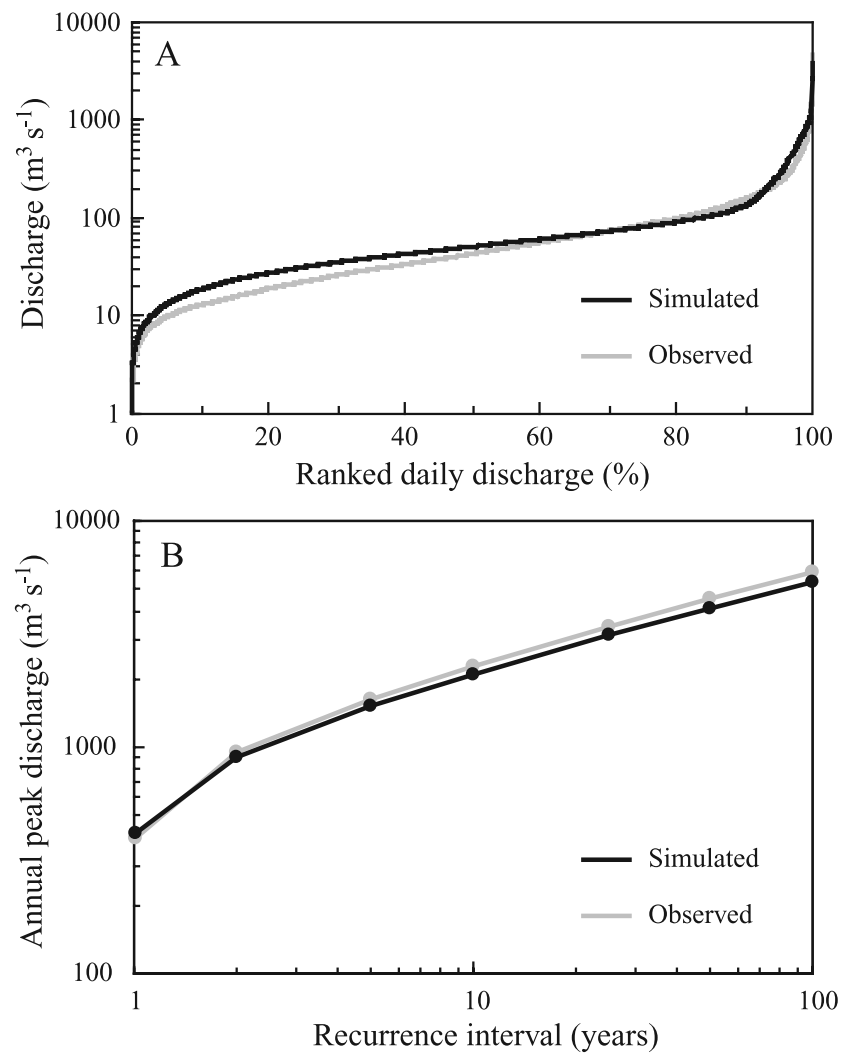

Figure 4. Comparison of (a) 25 years of ranked daily simulated and observed water discharges; and (b) observed and simulated flood frequencies in the Waipaoa River at Matawhero. The flood frequency curves were derived from 50 years of simulated and 25 years of observed data by fitting a log-Pearson type 3 probability distribution to the logarithm (base 10) of the annual maximum discharge.

[20] A magnitude-frequency analysis performed on 25 years of daily simulated water and suspended sediment discharge for the Waipaoa River at Matawhero indicates that the majority $(96 \%)$ of the sediment is transported at discharges less than bankfull (Figure 3). However, although frequent events are relatively more important than large floods to the simulated long-term suspended sediment discharge, extreme events also transport large amounts of sediment, and a single simulated storm event with a discharge of $3700 \mathrm{~m}^{3} \mathrm{~s}^{-1}$ generated $3.4 \%$ of the total sediment load for the 25-yr period (Figure 3 ). The former result is consistent with observation of Hicks et al. [2000, 2004] (based on gaugings made at Kanakanaia since 1960) that most $(86 \%)$ of the suspended sediment transport in the Waipaoa River is accomplished at discharges less than bankfull, and the latter with the contribution made by large magnitude-low frequency events that have been observed to generate nearly twice the annual basin suspended sediment discharge [Gomez et al., 1999; Hicks et al., 2000].

[21] HydroTrend's stochastic water discharge realizations cannot be compared directly with field data, because the simulated hydrograph is not equivalent to the observed sequence of events. Figure 4 provides a graphical comparison between ranked daily values of simulated water discharge and ranked observations for an equivalent 25-year period of record. A binned Chi-square analysis, incorporating 15 equally spaced subclasses [cf. Davis, 1986], suggests the model does not effectively reproduce the observed variability in water discharge $\left(P<0.01 ; \chi^{2}=\right.$ 422 with 15 degrees of freedom). However, a straightforward comparison between the two halves of the observed water discharge record also suggests the absence of first and second order stationarity in the field data $(P<0.01$; $\chi^{2}=242$ with 14 degrees of freedom). We applied same approach to the Te Arai and the Waimata rivers, for which there were 21 and $25 \mathrm{yr}$ of daily water discharge data, respectively (Figure 5). In these cases, $P<0.01 ; \chi^{2}=183$ and $\chi^{2}=161$, with 14 degrees of freedom, and splitting the observed water discharge records in half suggests first and second order stationarity also is absent in these data $\left(P<0.01 ; \chi^{2}=28\right.$ with 12 degrees of freedom, and $P<$ $0.01 ; \chi^{2}=88$ with 14 degrees of freedom, respectively). We did not investigate these effects further, but the simulations appear to capture the same order of goodness-of-fit to the field data as does a comparison between different sections of the observed water discharge record. It is on this basis that we use HydroTrend to simulate representative water discharges for the Waipaoa, Te Arai, and Waimata rivers.

[22] We used a two-sample Chi-square test to compare the simulated sediment concentrations to the concentrations obtained during $39 \mathrm{yr}$ of suspended sediment gaugings in the Waipaoa River (Figure 6). To compensate for the
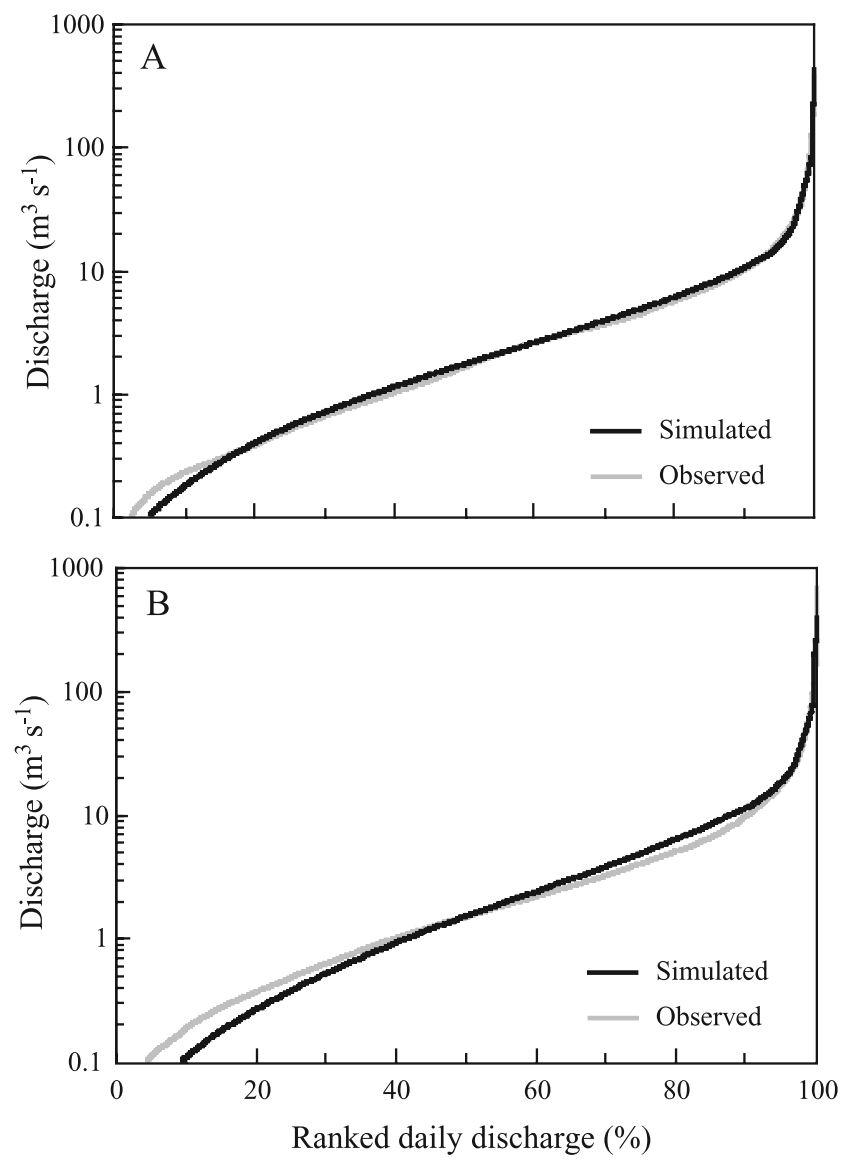

Figure 5. Comparison of 25 years of ranked daily simulated and observed water discharges in (a) the Te Arai River at Pike's Weir and (b) the Waimata River at Goodwin's Road. 


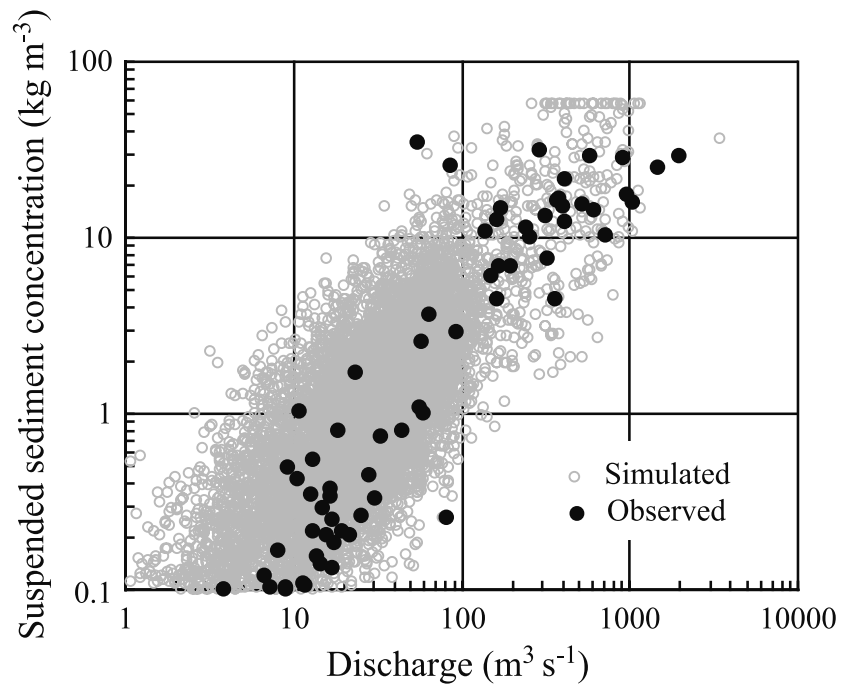

Figure 6. Comparison of 39 years of daily simulated and observed suspended sediment concentrations in the Waipaoa River at Matawhero.

nonrandom observed data, 10,000 subsets of 114 simulated sediment concentrations were selected, such that the water discharge distribution was identical to the observed distribution. The observed data $(N 1)$ and each subset of simulated sediment concentrations $(N 2)$ were ordered in classes (Figure 7a), and the 99\% confidence level established by determining the intrinsic variability of the simulated sediment concentrations with reference to the $\chi^{2}$ value for each simulated subset and that of the other simulated subsets:

$$
\chi^{2}=\sum_{x=1}^{m} \sum_{y=1}^{n} \frac{\left(N 1_{[x][y]}-N 2_{[x][y]}\right)^{2}}{\left(N 1_{[x][y]}+N 2_{[x][y]}\right)} \text { when } N 1, N 2>0
$$

where $m$ is the number of discharge subclasses and $n$ is the number of sediment concentration subclasses (Figure 7a). For the Waipaoa River, the internal model $\chi^{2}$ distribution (such that $N 1$ and $N 2$ are subsets of simulated sediment concentrations) has a value of 35.2 at the $99 \%$ confidence level (Figure 7b). The mean representative $\chi^{2}$ value of the data-model comparison is less than this critical $\chi^{2}$ value (the 50th percentile of the $\chi^{2}$ simulated-observed distribution and its standard error are $31.5 \pm 0.05$ ). It is to be expected that the modeled suspended sediment concentrations correspond with gaugings made in the $\mathrm{Te}$ Arai River because, as noted above, these data were employed to determine the adjustment to the rating curve exponent that was required to account for the higher suspended sediment concentrations observed in catchments where landsliding is the dominant erosion process (Figure 8a). However, we used the same approach to determine the goodness of fit of the modeled suspended sediment concentrations to the concentrations obtained during $25 \mathrm{yr}$ of suspended sediment gauging in the Waimata River (Figure 8b), in which shallow landsliding also imposes a threshold on sediment availability. In this case the internal model $\chi^{2}$ distribution has a value of 33.8 at the $99 \%$ confidence level (Figure $7 \mathrm{c}$ ), and the mean representative $\chi^{2}$ value of the data-model comparison is well below this critical $\chi^{2}$ value (the 50th percentile of the $\chi^{2}$
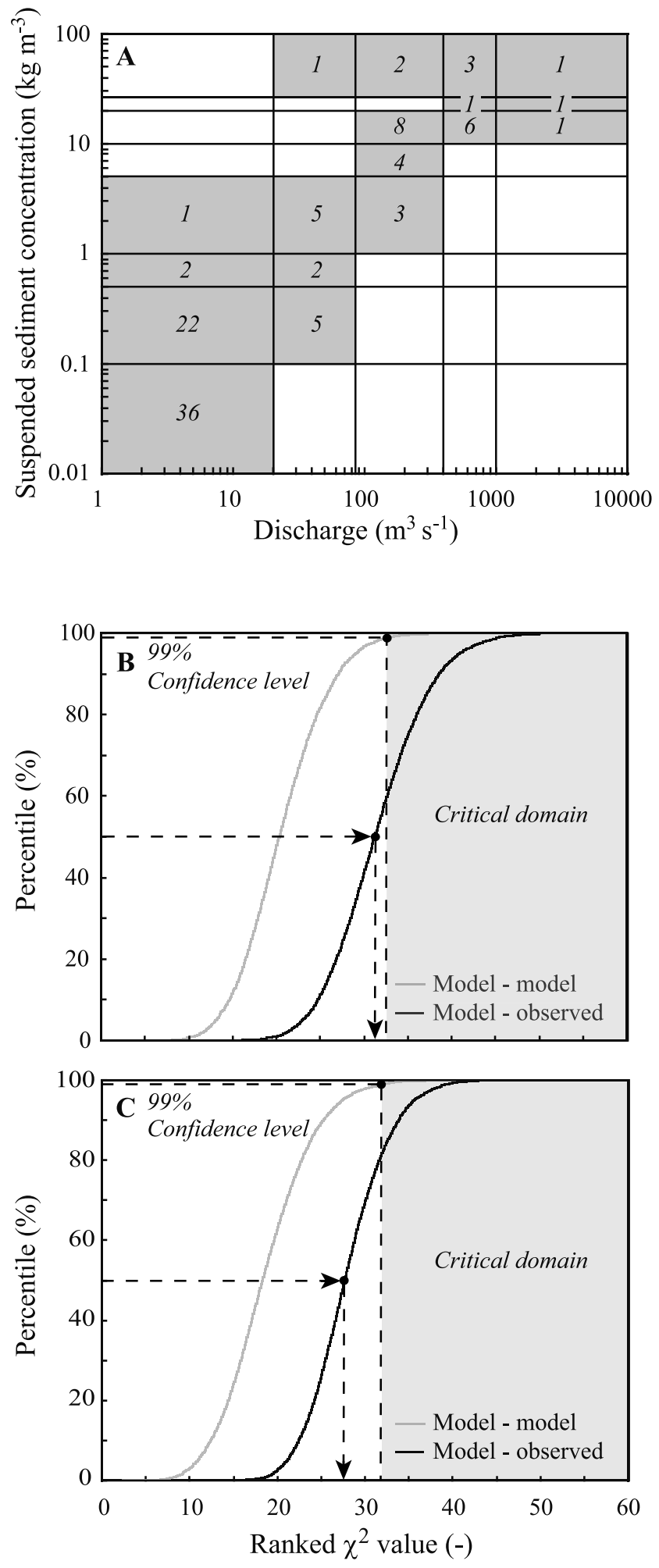

Figure 7. Distribution (a) of water discharge and concentration during 114 suspended sediment gaugings made in the Waipaoa River over a 39-yr period; and (b) ranked model-model comparison $\chi^{2}$ values and model-observed comparison $\chi^{2}$ values for the Waipaoa River; and (c) the Waimata River, determined from two sample Chi-square tests. Note that the 50th percentile of the model-observed comparison $\chi^{2}$ value for both the Waipaoa and the Waimata rivers is within the $99 \%$ confidence level (see text for discussion). 


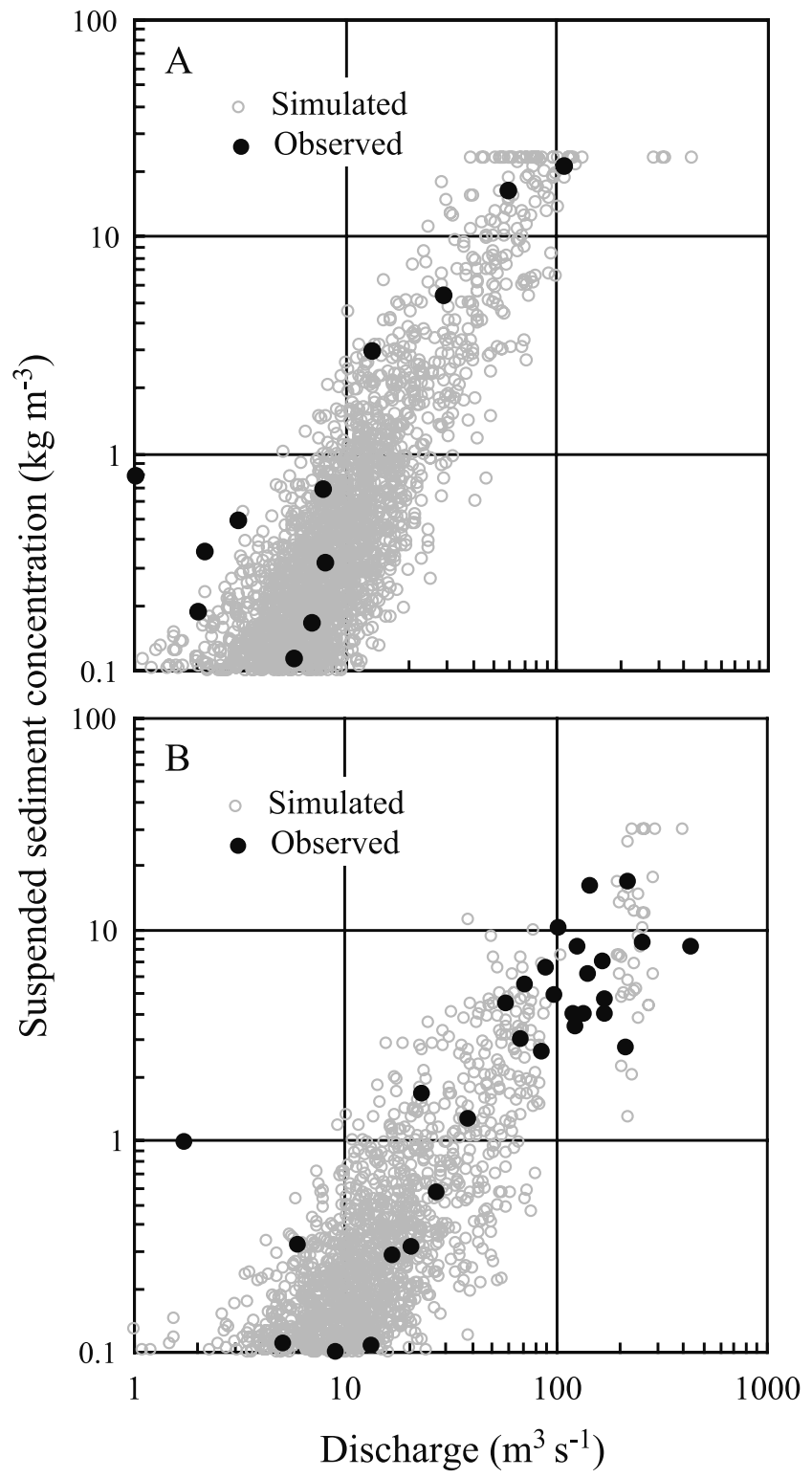

Figure 8. Comparison of 25 years of daily simulated and observed suspended sediment concentrations in (a) the Te Arai River at Pike's Weir; and (b) the Waimata River at Goodwin's Road.

simulated-observed distribution and its standard error is $28 \pm 0.04)$. Accordingly, we consider it practicable to use HydroTrend to simulate sediment concentrations in the Waipaoa River system over the past 3 Kyr.

\section{Late Holocene Variations in Water and Sediment Discharge}

[23] The results of the long-term simulation are presented in Figure 9, in which the annual water and suspended sediment discharge of the Waipaoa River system, normal-

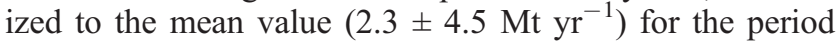
from 3000 to 1878 calendar years B.P. are represented as the sum of the values for the constituent catchments. This time period was selected as a baseline for reference purposes because it can be envisaged as a time when the vegetation cover and landscape of the Waipaoa River system were relatively stable, and subject only to occasional perturbations by natural events such as fires caused by lightning strikes and storms [Gomez et al., 2007]. One of the two principal components of climate (temperature) was held constant throughout the model runs. Perturbations to the other (precipitation) were driven by variability encountered in the proxy record of geomorphologically effective storm activity by Eden and Page [1998] (Figure 9). The amount of water lost by evapotranspiration also varies with the area of land covered by the three different vegetation types, but water discharge tracks the imposed variations in precipitation over time (Figure 9a), and the simulated data indicate that during wetter periods the average annual discharge may have been up to $\sim 20 \%$ higher than it is at present, and as much as $\sim 6 \%$ lower when drier conditions prevailed in the past. Water discharge increased by $\sim 4 \%$ in response to the land use changes effected in the historic period. Note that HydroTrend uses a random number generator to interpolate daily values from monthly temperature and precipitation data, and that each new model epoch (initiated by a change in climate and/or land use [cf. Syvitski et al., 1998]) commences with the same seed value [Syvitski et al., 1998]. This approach permits the model output to be reproduced, but it also introduces reiteration patterning into the time series, albeit with a unique mean and amplitude for each epoch (Figure 9a).

[24] Climate exerts a fundamental control on hillslope stability by determining the amount of runoff [Melton, 1957], and water and suspended sediment discharge are connected by means of the rating relation. Thus variations in suspended sediment discharge mimic those in water discharge, but the overall response to changes in the precipitation regime is more subdued. For example, a $10 \%$ increase in precipitation produces a $5 \%$ increase in simulated suspended sediment discharge. This is because precipitation influences suspended sediment discharge by way of water discharge [equation (9)]. Moreover, with relief, temperature, and the related coefficients held constant, a change in the vegetation-erosion index (that characterizes the effect a disturbance to the vegetation cover has on the erodibility of the underlying rocks) potentially may have a more pronounced effect on suspended sediment discharge than a variation in precipitation that serves as a proxy for a short-term change in the climatic regime as a whole [cf. Milliman and Syvitski, 1992; Syvitski et al., 2003]. Accordingly, relative to the period prior to 1878 calendar years B.P., the simulated suspended sediment discharge increases by $350 \%$ (to $8.0 \pm 24.3 \mathrm{Mt} \mathrm{yr}^{-1}$ ) after European arrival when pastoral farming began on the low-

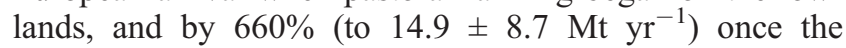
headwaters were deforested (because previous comparisons were based on different time periods, the latter value differs from preliminary estimate quoted elsewhere [e.g., Phillips et al., 2007]). However, suspended sediment discharge begins to decline in the post 1960 A.D. period, when large tracts of grassland in the headwaters were reforested (Figure 9). By comparison there is only a small, $140 \%$

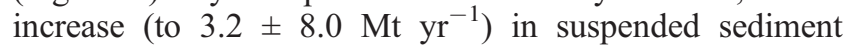
discharge following Polynesian arrival. This is consistent with the view that, although Maori habitually utilized fire to 

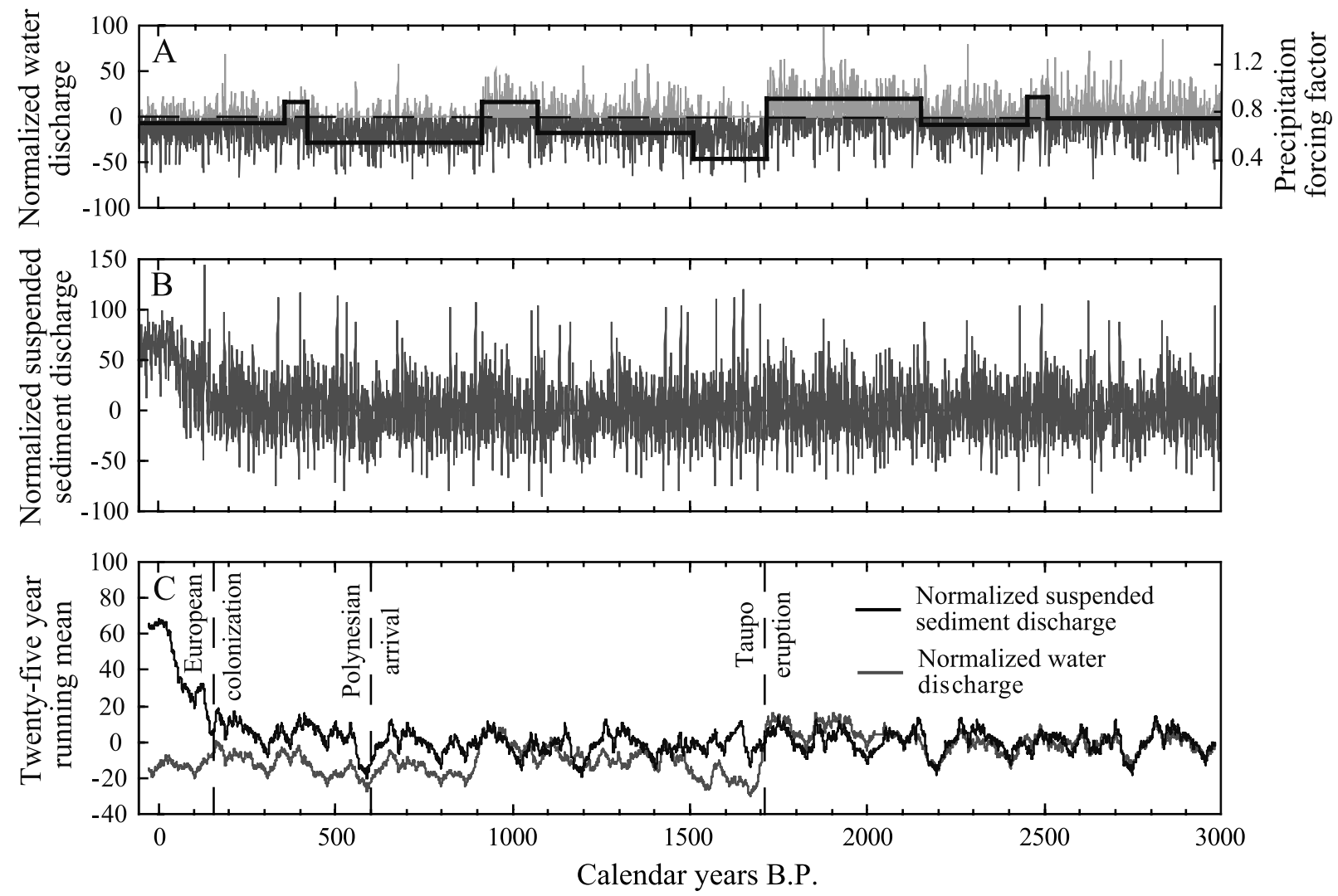

Figure 9. Simulated (a) water and (b) suspended sediment discharge time series for the Waipaoa River system in the last $3 \mathrm{Kyr}$ (commencing 2000 A.D.) normalized to the respective mean values for the period from 3000 to 1878 calendar years B.P. (see text for discussion). Note that water discharge tracks climate (solid line) as forced by variations in the frequency of geomorphically effective storms (data from Eden and Page [1998]), drier periods (negative offsets) are represented by dark and wetter (positive offsets) by light shading, and that although the time-variations mimic those in water discharge changes in land use have more a profound effect on suspended sediment discharge. A 25-yr running mean is used to highlight long-term trends in the normalized water and suspended sediment discharge time series (c) and their relation to vegetation/land-use change by natural events and anthropogenic activity.

open and maintain tracks and dwelling areas, to clear ground for cultivation, and to encourage the growth of Pteridium (which provided a source of carbohydrate [McGlone, 1989; McGlone et al., 2005]), only a small percentage of total basin area would have been affected by individual burns. Large storms also have no lasting effect on suspended sediment discharge because they release sediment from point sources that stabilize relatively rapidly [cf. Trustrum et al., 1999]. Following the Taupo eruption suspended sediment discharge increased by $190 \%$ (to $4.2 \pm$

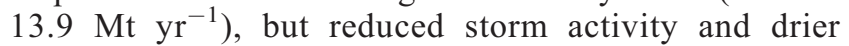
conditions overall muted the long-term impact that the widespread and protracted [cf. Wilmshurst et al., 1997], post-Taupo disruption to the vegetation cover had on suspended sediment discharge.

[25] Deforestation is known to have had an equally pronounced impact on sediment fluxes in other parts of the world [Hewawasam et al., 2003; Dearing and Jones, 2003], but the simulations suggest the program of wholesale land use change implemented after European colonization had a far greater impact on the suspended sediment discharge from the Waipaoa River system than any other category of late Holocene environmental change. It is difficult to evaluate this result and the model output directly because the frequency and distribution of flood events and the relation between suspended sediment and water discharge are known for only a small portion of the late Holocene. However, because the sources and sinks in the dispersal system are closely linked [Gomez et al., 2004a], it is possible to effect a first-order comparison between trends in the simulated suspended sediment discharge time series and the flux of fine terrigenous sediment to the middle shelf at core site MD972122 (Figure 1), determined from the sediment bulk density and time-averaged accumulation rate [Gomez et al., 2007]. The latter maintains a relatively low value until European settlers deforested the headwaters (Figure 10). Thereafter, there is a pronounced increase and a subsequent small decline in sediment flux (cf. Figure 9b), that reflect gully initiation following deforestation and stabilization in response to the encroachment of bracken and native regenerating species prior to reforestation, respectively [Allsop, 1973]. Thus despite obvious differences in resolution, the model output is consistent with sedimentary record preserved on the middle shelf. Both time series register the same dramatic response to the land use changes implemented by European colonists, and a much 


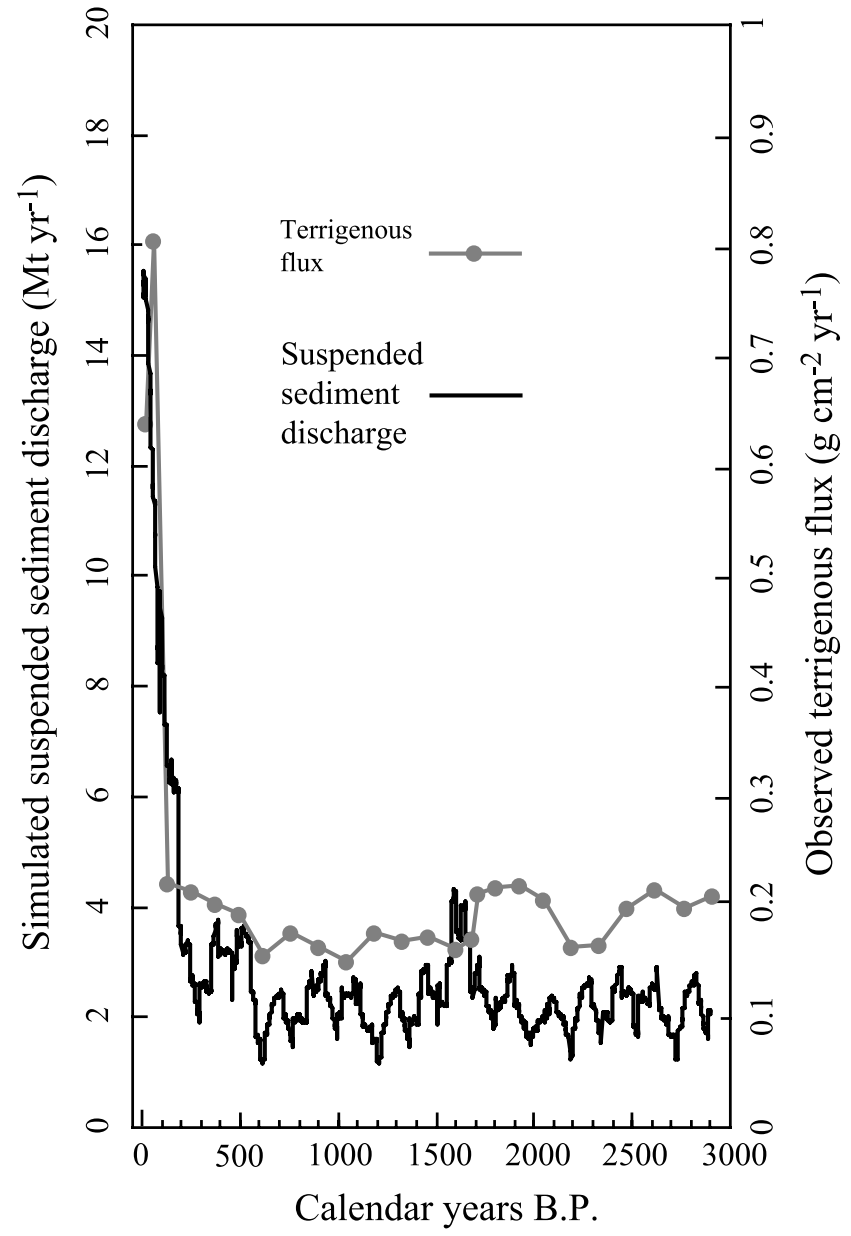

Figure 10. Comparison of the late Holocene suspended sediment discharge (99-yr running mean) from the Waipaoa River system computed using HydroTrend and the observed rate of terrigenous mass accumulation on the middle shelf at core site MD972122 [after Gomez et al., 2007] (see Figure 1 for location).

more subdued response to other categories of late Holocene environmental change.

[26] It is pertinent to enquire why, when viewed against the background of late Holocene environmental change as a whole, deforestation of the headwaters had such a profound impact on suspended sediment discharge? Changes in storage effectively mask the effect variations in sediment production have on sediment discharge yield only if storage is large relative to yield, and where the residence time of the alluvium is long relative to the timescale of environmental change [Phillips, 2003], but neither scenario applies to the Waipaoa River system [Phillips et al., 2007; Phillips and Gomez, 2007]. Relief, by contrast, provides a critical first-order control on mechanical denudation and helps sustain a "metabolic" rate of erosion that dominates over long time periods [Milliman and Syvitski, 1992; Gunnell, 1998; Syvitski et al., 2003]. In the short term, increased erosion that is, for example, a product of climate or land use change produces a spike in the metabolic rate, the strength of which reflects the intensity of erosion processes involved.
Singular events, such as volcanic eruptions, have the potential to disrupt the vegetation cover over a wide area, temporarily lower the threshold of landscape sensitivity as a whole, and initiate a step-function change in material fluxes [Trustrum et al., 1999]. Similarly, the gradual changes to the native vegetation that occurred after Polynesian arrival lowered the threshold for hillslope erosion by landsliding and scour by surface runoff. However, the impact these and other essentially temporally sensitive phenomena have on suspended sediment discharge is determined by events of high magnitude and low frequency, and decays incrementally [Pain and Hoskin, 1970; Trustrum et al., 1999; Hicks et al., 2000]. In short, their effect in the prehistoric period was conditioned by the hydrology of the contributing rivers.

[27] The tempo of erosion increased after European colonists cleared the lowland forests, but the deforestation of the headwaters completely redefined the sensitivity of the landscape to erosion but not, in this case, the hydrological regime. This wholesale change in land use profoundly affected geomorphic processes and sediment production by oversteepening hillslopes and precipitating the welldocumented shift in process dominance, from an erosional regime dominated by shallow landsliding and other diffusive processes, including earthflows and sheet erosion, to one where incisive processes (for example, gully erosion), generate most of the sediment transported by the Waipaoa River [Hicks et al., 2000; Gomez et al., 2004b]. The historic change in land use had such a profound effect on suspended sediment discharge because gully erosion does not involve a threshold limitation on sediment supply, and impacts sediment production and dispersal across the entire magnitudefrequency spectrum of events that regulate sediment delivery to and transport in stream channels [cf. Hicks et al., 2000]. The subsequent encroachment of bracken and native vegetation and later reforestation with exotic species reduced the area affected by gully erosion [Marden et al., 2005], and brought about a decline in suspended sediment discharge (and in the flux of terrigenous mud to the middle shelf).

[28] Finally, the model output provides a perspective on the vexed question of how frequently events that have the potential to generate hyperpycnal discharges occur in the Waipaoa River [Hicks et al., 2004]. A common criterion for the formation of hyperpycnal plumes is that the density of the sediment-laden river outflow exceeds that of the ambient ocean water density [Mulder and Syvitski, 1995]. On this basis the critical suspended sediment concentration required to produce a hyperpycnal plume is $\sim 40 \mathrm{~kg} \mathrm{~m}^{-3}$. Under present conditions the Waipaoa River potentially appears able to generate hyperpycnal plumes (Figure 11). However, although it is possible that the critical suspended sediment concentration was exceeded during catastrophic floods in the period before records began [cf. Gomez et al., 2007] (which the model does not accommodate), the threshold does not appear to have been approached in the period prior to European arrival, and not even the widespread and protracted disturbance to the vegetation cover caused by the Taupo eruption had as profound an influence on either the $y$ axis intercept or slope of the rating curve as did deforestation of the headwaters (Figure 11). In this context we note that the $y$ axis intercept and slope of the rating curve indicate the extent to which new sediment sources 

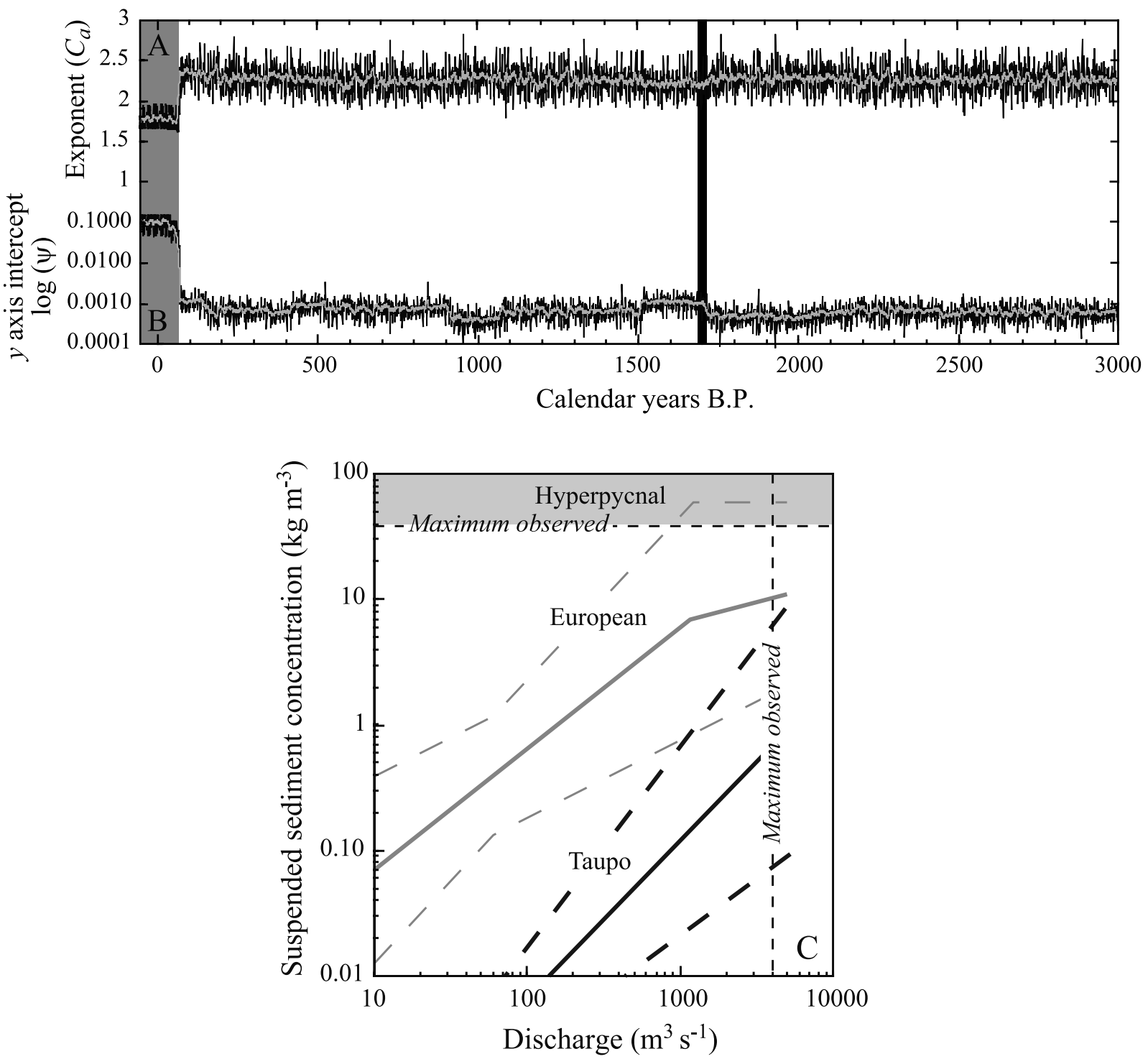

Figure 11. Time-variations in values of (a) the rating exponent and (b) coefficient $[y$ axis intercept, $\log (\Psi)$ values] incorporated in the psi $(\Psi)$ equation embedded in HydroTrend. Trends are highlighted using a 10-yr running mean (solid lines), and the boxes delimit the two time periods for which the simulated rating curves are shown. (c) Rating curves for the periods following the Taupo eruption and deforestation of the headwaters of the Waipaoa River system. Dashed lines delimit the upper and lower boundaries of the rating relations and shading suspended sediment concentrations sufficient to generate hyperpycnal flows.

become available as discharge increases, and can be interpreted as indices of erosion severity (high values denote strongly weathered easy transportable materials) and a river's erosive power, respectively [Peters-Kümmerly, 1973; Asselman, 2000].

\section{Conclusions}

[29] Previous studies have shown that the discharge of water and sediment to the ocean depends on climate and local drainage basin characteristics [Milliman and Syvitski, 1992; Mulder and Syvitski, 1996], and this knowledge has been used to develop a numerical model, HydroTrend, that can simulate natural variability in water and suspendedsediment discharges over very long periods of time [Syvitski et al., 1998; Kettner and Syvitski, submitted manuscript, 2007]. Informed by the observed erosional response to changes in land use, vegetation type and climatic regime, and information derived from climatological stations with between 9 and 78 years of exploitable record and a $25-\mathrm{m}$ DEM, HydroTrend was used to assess the relative impact different categories of late Holocene environmental change had on water and suspended sediment discharge in the Waipaoa River system during past $3 \mathrm{Kyr}$. It is difficult to verify model predictions because river basins evolve as open systems in which the initial and boundary conditions are uncertain and, for the most part, unverifiable. However, the model output replicates both the frequency and distribution of flow events and the suspended sediment concen- 
tration-discharge relationship, and provides a consistent and reassuringly unexaggerated match to contemporary observations made in the Waipaoa, Te Arai, and Waimata rivers (Figures 4-8). The results from the long-term simulation also are consistent with the sedimentary record preserved on the middle shelf (Figure 10).

[30] Water discharge tracks imposed variations in precipitation over time (Figure 9), and during wetter periods the average annual discharge may have been up to $\sim 20 \%$ higher than it is at present, and as much as $\sim 6 \%$ lower when drier conditions prevailed in the past. Deforestation in the historic period caused water discharge to increase by $\sim 4 \%$. Variations in suspended sediment discharge mimic those in water discharge but the overall response to changes in the precipitation regime is more subdued, and a $10 \%$ increase in precipitation produces a 5\% increase in suspended sediment discharge (Figure 9b). Compared to the period prior to 1878 calendar years B.P. (when the vegetation cover and landscape of the Waipaoa River system were subject only to natural perturbations by fire and storms), after the Taupo eruption suspended sediment discharge increased by $190 \%$, but reduced storm activity and drier conditions overall diminished the impact this event had in the long term. Comparison with the same reference period indicates that after Polynesian settlements were established suspended sediment discharge increased by $140 \%$, whereas the wholesale land use changes effected by European colonists initially caused suspended sediment discharge to increase by $350 \%$, and by $660 \%$ once the headwaters were deforested. Thereafter, reforestation of erosion-prone land in the headwaters caused suspended sediment discharge to decline slightly (Figure 10). Nevertheless, even under the contemporary hydrogeomorphological regime, suspended sediment concentrations in the Waipaoa River system rarely approach the threshold for hyperpycnal plume generation (Figure 11). The magnitude of the change in suspended sediment discharge during the Anthropocene appears large (from $2.3 \pm 4.5$ to $14.9 \pm 8.7 \mathrm{Mt} \mathrm{yr}^{-1}$ ). However, it remains that, by comparison with contemporary measurements made in other small steepland rivers [cf. Milliman and Syvitski, 1992], even under the conditions that prevailed prior to the arrival of humans the Waipaoa River system transported a very large amount of suspended sediment for its size.

[31] The historic changes in land use (replicated in the model by changing the vegetation-erosion index) had such a profound effect on suspended sediment discharge because they brought about the transition to an erosional regime that does not involve a threshold limitation on sediment supply, and impacts sediment production and dispersal across the entire magnitude-frequency spectrum of events that regulate sediment delivery to and transport in stream channels. By contrast, the impact environmental change in the prehistoric period had on suspended sediment discharge is conditioned, through the medium of events of high magnitude and low frequency, by the hydrology of the contributing rivers and is more muted.

[32] Acknowledgments. This work has been supported by the National Science Foundation grant BCS-0317570. We thank Dave Peacock and Ross Bannister (Gisborne District Council) for providing climate, water discharge and suspended sediment load data; Landcare Research Ltd. for the vegetation classification and access to the DEM; Gert Jan Weltje for help with the statistical analyses; and two anonymous reviewers for their comments.

\section{References}

Allsop, F. (1973), The Story of Mangatu, Government Printer: Wellington, New Zealand, $100 \mathrm{p}$.

Asselman, N. E. M. (2000), Fitting and interpretation of sediment rating curves, J. Hydrol., 234, 228-248.

Berryman, K. R., Y. Ota, and A. G. Hull (1989), Holocene paleoseismicity in the fold and thrust belt of the Hikurangi subduction zone, eastern North Island, New Zealand, Tectonophysics, 163, 185-195.

Berryman, K. R., M. Marden, D. N. Eden, C. Mazengarb, Y. Ota, and I. Moriya (2000), Tectonic and paleoclimatic significance of Quaternary river terraces of the Waipaoa River, east coast, New Zealand, New Zealand Journal of Geology and Geophysics, 43, 229-245.

Blum, M. D., and T. Törnqvist (2000), Fluvial responses to climate and sealevel change: A review and look forward, Sedimentology, 47, 2-48.

Brown, L. J. (1995), Holocene shoreline depositional processes at Poverty Bay, a tectonically active area, northeastern North Island, New Zealand, Quat. Int., 26, 21-33.

Burrows, C. J., and D. E. Greenland (1979), An analysis of the evidence for climatic change in New Zealand in the last thousand years: Evidence from diverse natural phenomena and from instrumental records, $J . R$. Soc. N. Z., 9, 321-373.

Campbell, D. A. (1996), History of accelerated soil erosion and its implications, Unpublished Report to the East Cape Catchment Board, 3 p. + appendices.

Carter, L., B. Manighetti, M. Elliot, N. Trustrum, and B. Gomez (2002), Source, sea level and circulation effects on the sediment flux to the deep ocean over the past 15 ka off eastern New Zealand, Global Planet. Change, 33, 339-355.

Crawford, C. R. (1991), Estimation of suspended-sediment rating curves and mean suspended-sediment loads, J. Hydrol., 129, 331-348.

Davis, J. C. (1986), Statistics and data analysis in Geology, 2nd edition, 646 p, John Wiley, Hoboken N. J.

Dearing, J. A., and R. T. Jones (2003), Coupling temporal and spatial dimensions of global sediment flux through lake and marine sediment records, Global Planet. Change, 39, 147-168.

Derose, R. C., B. Gomez, M. Marden, and N. A. Trustrum (1998), Gully erosion in Mangatu Forest, New Zealand, estimated from digital elevation models, Earth Surf. Processes Landforms, 23, 1045-1053.

Eden, D. N., and M. J. Page (1998), Palaeoclimatic implications of a storm erosion record from late Holocene lake sediments, North Island, New Zealand, Palaeogeogr. Palaeoclimatol. Palaeoecol., 139, 37-58.

Ferguson, R. I. (1987), Accuracy and precision of methods for estimating river loads, Earth Surf. Processes Landforms, 12, 95-104.

Fuller, C. W., S. D. Willett, N. Hovius, and R. Slingerland (2003), Erosion rates for Taiwan mountain basins: New determinations for suspended sediment records and a stochastic model of their temporal variation, J. Geol., 111, 71-87.

Gabet, E. J., D. W. Burbank, J. K. Putkonen, B. A. Pratt-Sitaula, and T. Ojha (2004), Rainfall thresholds for landsliding in the Himalayas of Nepal, Geomorphology, 63, 131-143.

Gage, M., and D. Black (1979), Slope stability and geological investigations at Mangatu State Forest. Technical Paper, 66, 47 p., Forest Research Institute, New Zealand Forest Service, Wellington, New Zealand.

Gomez, B., D. N. Eden, D. M. Hicks, N. A. Trustrum, D. H. Peacock, and J. Wilmshurst (1999), Contribution of floodplain sequestration to the sediment budget of the Waipaoa River, New Zealand, in Floodplains: Interdisciplinary Approaches, edited by S. B. Mariott and J. Alexander, Geological Society Special Publication, 163, 69-88.

Gomez, B., M. J. Page, P. Bak, and N. A. Trustrum (2002), Self-organized criticality in layered, lacustrine sediments formed by landsliding, Geology, $30,519-522$.

Gomez, B., N. A. Trustrum, D. M. Hicks, M. J. Page, K. M. Rogers, and K. R. Tate (2003), Production, storage and output of particulate organic carbon: Waipaoa River Basin, New Zealand, Water Resour. Res., 39(6), 1161, doi:10.1029/2002WR001619.

Gomez, B., L. Carter, N. A. Trustrum, A. S. Palmer, and A. P. Roberts (2004a), El Niño-Southern Oscillation signal associated with middle Holocene climate change in intercorrelated terrestrial and marine sediment cores, North Island, New Zealand, Geology, 32, 653-656.

Gomez, B., H. L. Brackley, D. M. Hicks, H. Neff, and K. M. Rogers (2004b), Organic carbon in floodplain alluvium, signature of historic variations in erosion processes associated with deforestation, Waipaoa River basin, New Zealand, J. Geophys. Res., 109, F04011, doi:10.1029/ 2004JF000154.

Gomez, B., S. E. Coleman, V. W. K. Sy, D. H. Peacock, and M. Kent (2006), Channel change, bankfull and effective discharges on a vertically 
accreting, meandering, gravel-bed river, Earth Surf. Processes Landforms, doi:10.1002/esp.1424

Gomez, B., L. Carter, and N. A. Trustrum (2007), A 2400 yr Record of Natural Events and Anthropogenic Impacts in Inter-Correlated Terrestrial and Marine Sediment Cores: Waipaoa Sedimentary System, New Zealand, Geol. Soc. Am. Bull., in press.

Grant, P. J. (1989), Effects on New Zealand vegetation of late Holocene erosion and alluvial sedimentation, N. Z. J. Ecol., 12(supplement), 131144.

Gunnell, Y. (1998), Present, past and potential denudation rates: is there a link? Tentative evidence from fission-track data, river sediment loads and terrain analysis in the South Indian shield, Geomorphology, 25, 135153.

Guthrie-Smith, H. G. (1969), Tutira: The story of a New Zealand Sheep Station, 464 p, A. H. and A. W. Reed, Wellington.

Hastings, P. A. (1990), Southern Oscillation influences on tropical cyclone activity in the Australian/Southwest Pacific region, Int. J. Climatol., 10, 291-298.

Hessell, J. W. D. (1980), The climate and weather of the Gisborne region, N. Z. Meterol. Serv. Misc. Publ., 115(8), 29 p.

Hewawasam, T., F. von Blanckenburg, M. Schaller, and P. Kubik (2003), Increase of human over natural erosion rates in tropical highlands constrained by cosmogenic nuclides, Geology, 31, 597-600.

Hicks, D. M., and B. Gomez (2003), Sediment transport, in Tools in Fluvial Geomorphology, edited by G. M. Kondolf and H. Piégay, 425-461, John Wiley, Hoboken N. J.

Hicks, D. M., B. Gomez, and N. A. Trustrum (2000), Erosion thresholds and suspended sediment yields, Waipaoa River Basin, New Zealand, Water Resour. Res., 36, 1129-1142.

Hicks, D. M., B. Gomez, and N. A. Trustrum (2004), Event suspended sediment characteristics and the generation of hyperpycnal plumes at river mouths: East coast continental margin, North Island, New Zealand, J. Geol., 112, 471-485.

Horowitz, A. J. (2003), An evaluation of sediment rating curves for estimating suspended sediment concentrations for subsequent flux calculations, Hydrol. Processes, 7, 3387-3409.

Hovius, N., C. P. Stark, C. Hao-Tsu, and L. Jiun-Chuan (2000), Supply and removal of sediment in a landslide-dominated mountain belt: Central Range, Taiwan, J. Geol., 108, 73-89.

Jakob, M., and H. Weatherly (2003), A hydroclimatic threshold for landslide initiation on the North Shore Mountains of Vancouver, British Columbia, Geomorphology, 54, 137-156.

Jessen, M. R., T. F. Crippen, M. J. Page, W. C. Rijkse, G. R. Harmsworth, and M. McLeod (1999), Land use capability classification of the Gisborne-East Coast region, Landcare Res. Sci. Ser., 21, 213 p.

Kasai, M., T. Marutani, L. M. Reid, and N. A. Trustrum (2001), Estimation of temporally averaged sediment delivery ratio using aggradational terraces in headwater catchments of the Waipaoa River, North Island, New Zealand, Earth Surf. Processes Landforms, 26, 1-16.

Kelsey, H. M. (1980), A sediment budget and an analysis of geomorphic process in the Van Duzen River basin, north coastal California, 19411975, Geol. Soc. Am. Bull., 91, 1119-1216, Part 2.

Kettner, A. J., and J. P. M. Syvitski (2007), Predicting discharge and sediment flux of the Po River, Italy since the last glacial maximum, in Analogue and Numerical Forward Modelling of Sedimentary Systems; from Understanding to Prediction: International Association of Sedimentologists, edited by P. L. de Boer et al., special publication 39.

Leithold, E. L., D. W. Perkey, N. E. Blair, and T. N. Creamer (2005), Sedimentation and carbon burial on the northern California continental shelf: The signatures of land-use change, Cont. Shelf Res., 25, 349-371.

Liébault, F., B. Gomez, M. J. Page, M. Marden, D. H. Peacock, D. Richard, and C. M. Trotter (2005), Land-use change, sediment production and channel response in upland regions, River Res. Appl., 21, 739-756.

Lyons, W. B., C. A. Nezat, A. E. Carey, and D. M. Hicks (2002), Organic carbon fluxes to the ocean from high-standing islands, Geology, 30, $443-446$.

Marden, M., G. Arnold, B. Gomez, and D. Rowan (2005), Pre- and postreforestation gully development in Mangatu Forest, East Coast, North Island, New Zealand, River Res. Appl., 21, 757-771.

Mazengarb, C., and I. G. Speden (2000), Geology of the Raukumara Area, 1:250,000 Geological Map 6, 1 sheet +60 p., Institute of Geological and Nuclear Sciences, Lower Hutt.

McGlone, M. S., A. P. Kershaw, and V. Markgraf (1992), Southern Oscillation climatic variability in Australasia and South American paleoenvironmental records, in El Niño: Historical and Paleoclimatic Aspects of the Southern Oscillation, edited by H. F. Diaz and V. Markgraf, pp. 435-462, Cambridge Univ. Press, New York.
Métivier, F., and Y. Gaudemar (1999), Stability of output fluxes of large rivers in south and east Asia during the last 2 million years: Implications on floodplain processes, Basin Res., 11, 293-303.

Meybeck, M., L. Laroche, H. H. Dürr, and J. P. M. Syvitski (2003), Global variability of daily total suspended solids and their fluxes in rivers, Global Planet. Change, 39, 65-93.

McGlone, M. S. (1989), The Polynesian settlement of New Zealand in relation to environmental and biotic changes, N. Z. J. Ecol., 12, 115129.

McGlone, M. S., M. J. Salinger, and N. T. Moar (1993), Paleovegetation studies of New Zealand's climate since the last glacial maximum, in Global climates since the Last Glacial Maximum, edited by H. E. Wright et al., 294-317 University of Minnesota, Minneapolis.

McGlone, M. S., J. M. Wilmshurst, and H. M. Leach (2005), An ecological and historical review of bracken (Pteridium esculentum) in New Zealand, and its cultural significance, $N$. Z. J. Ecol., 29, 165-184.

Melton, M. A. (1957), An analysis of the relations among elements of climate, surface properties and geomorphology, Department of Geology, Columbia University, New York, Technical Report 11, 102 p.

Meybeck, M., and C. Vörösmarty (2005), Fluvial filtering of land-to-ocean fluxes: From natural Holocene variations to Anthropocene, C. R. Géosci., $337,107-123$.

Milliman, J. D., and J. P. Syvitski (1992), Geomorphic/tectonic control of sediment discharge to the ocean: The importance of small mountainous rivers, J. Geol., 100, 525-544.

Morehead, M. D., J. P. Syvitski, E. W. H. Hutton, and S. D. Peckham (2003), Modeling the temporal variability in the flux of sediment from ungauged river basins, Global Planet. Change, 39, 95-110.

Mulder, T., and J. P. M. Syvitski (1995), Turbidity currents generated at river mouths during exceptional discharges to the world oceans, J. Geol., 103, 285-299.

Mulder, T., and J. P. M. Syvitski (1996), Climatic and morphologic relationships of rivers: Implications of sea level fluctuations on river loads, $J$. Geol., 104, 509-523.

Murton, B. J. (1968), Mapping the immediate pre-European vegetation on the East coast of the North Island of New Zealand, Prof. Geogr., 20, $262-264$.

Noren, A. J., P. R. Bierman, E. J. Steig, A. Lini, and J. Southon (2002), Millennial-scale storminess variability in the northeastern United States during the Holocene epoch, Nature, 419, 821-824.

Page, M. J., and N. A. Trustrum (1997), A late Holocene lake sediment record response to land use change in a steepland catchment, New Zealand, Z. Geomorphol. N.F., 41, 369-392.

Pain, C. F., and P. L. Hoskin (1970), The movement of sediment in a channel in relation to magnitude and frequency concepts-A New Zealand example, Earth Sci. J., 4, 17-23.

Pearce, A. J., L. O'Loughlin, R. J. Jackson, and X. B. Zhang (1987), Reforestation: On-site effects on hydrology and erosion, eastern Raukumara Range, New Zealand, in Forest Hydrology and watershed management, edited by R. H. Swanson, P. Y. Bernier, and P. D. Woodard, 167, 489-497, International Association of Hydrological Sciences.

Peters-Kümmerly, B. E. (1973), Untersuchungen über Zusammensetzung und Transport von Schwebstoffen in einigen Schweizer Flüssen, Geogr. Helv., 28, 137-151.

Phillips, J. D. (2003), Alluvial storage and the long term stability of sediment yields, Basin Res., 15, 153-163.

Phillips, J. D., and B. Gomez (2007), Controls on sediment export from the Waipaoa River basin, New Zealand, Basin Res., doi:10.1111/j.13652117.2007.00325.x, in press.

Phillips, J. D., M. Marden, and B. Gomez (2007), Residence time of alluvium in an aggrading fluvial system, Earth Surf. Processes Landforms, 32, 307-316, doi:10.1002/esp. 1385

Pullar, W. A. (1962), Soils and agriculture of Gisborne Plains, Bulletin 20, 92 p. N.Z. Soil Bur., Wellington.

Pullar, W. A., and H. R. Penahle (1970), Periods of recent infilling of the Gisborne Plains, N. Z. J. Sci., 13, 410-434.

Reid, L. M., and M. J. Page (2002), Magnitude and frequency of landsliding in a large New Zealand catchment, Geomorphology, 49, $71-88$.

Salinger, M. J., and A. B. Mullen (1999), New Zealand Climate: Temperature and precipitation variations and their links with atmospheric circulation 1930-1994, Int. J. Climatol., 19, 1049-1071.

Scott, D. T., W. T. Baisden, R. J. Davis-Colley, B. Gomez, D. M. Hicks, M. J. Page, N. J. Preston, N. A. Trustrum, K. R. Tate, and R. A. Woods (2006), Localized erosion affects national carbon budget, Geophys. Res. Lett., 33, L01402, doi:10.1029/2005GL024664. 
Shulmeister, J., et al. (2004), The Southern Hemisphere westerlies in the Australasian sector over the last glacial cycle: A synthesis, Quat. Int., $118-119,23-53$.

Sommerfield, C. K., D. E. Drake, and R. A. Wheatcroft (2002), Shelf record of climatic changes in flood magnitude and frequency, northcoastal California, Geology, 30, 395-398

Summerfield, M. A., and N. J. Hulton (1994), Natural controls of fluvial denudation rates in major world drainage basins, J. Geophys. Res., 99B, $135-153$.

Syvitski, J. P. M., and J. D. Milliman (2007), Geology, geography and humans battle for dominance over the delivery of fluvial sediment to the coastal ocean, J. Geol., 115, 1-19.

Syvitski, J. P. M., and M. D. Morehead (1999), Estimating river-sediment discharge to the ocean: application to the Eel margin, northern California, Mar. Geol., 154, 13-28.

Syvitski, J. P. M., M. D. Morehead, and M. Nicholson (1998), HydroTrend: A climate-driven hydrologic-transport model for predicting discharge and sediment load to lakes or oceans, Comput. Geosci., 24, 51-68.

Syvitski, J. P. M., M. D. Morehead, D. B. Bahr, and T. Mulder (2000), Estimating fluvial sediment transport: The rating parameters, Water Resour. Res., 36, 2747-2760.

Syvitski, J. P. M., S. D. Peckham, R. Hilberman, and T. Mulder (2003), Predicting the terrestrial flux of sediment to the global ocean: A planetary perspective, Sediment. Geol., 162, 5-24.

Syvitski, J. P. M., C. J. Vörösmarty, A. J. Kettner, and P. A. Green (2005), Impact of humans on the flux of terrestrial sediment to the global coastal ocean, Science, 308, 376-380.

Trustrum, N. A., B. Gomez, M. J. Page, L. M. Reid, and D. M. Hicks (1999), Sediment production, storage and output: The relative role of large magnitude events in steepland catchments, Z. Geomorphol. N.F., $115,71-86$
Veldkamp, A., and L. A. Tebbens (2001), Registration of abrupt climate changes within fluvial systems: Insights from numerical modeling experiments, Global Planet. Change, 28, 129-144.

Waipaoa Catchment Study Project Team (1994), Waipaoa Catchment Study: Literature Review, 122 p., Manaaki Whenua-Landcare Research, Palmerston North.

Walling, D. E., and D. Fang (2003), Recent trends in the suspended sediment loads of the world's rivers, Global Planet. Change, 39, 111-126.

Wang, Y., M.-e. Ren, and J. P. M. Syvitski (1997), Sediment transport and terrigenous fluxes, in The Sea, Volume 10- The Global Coastal Ocean: Processes and Methods, edited by A. R. Robinson and K. H. Brink, 346-401, John Wiley, Hoboken, N. J.

Wilby, R. L., H. Y. Dalgleish, and I. D. L. Foster (1997), The impact of weather patterns on historic and contemporary catchment sediment yields, Earth Surf. Processes Landforms, 22, 353-363.

Wilmshurst, J. M., M. S. McGlone, and T. R. Partridge (1997), A late Holocene history of natural disturbance in lowland podocarp/hardwood forest, Hawke's Bay, New Zealand, N. Z. J. Bot., 35, 79-96.

Wilmshurst, J. M., N. D. Eden, and P. C. Froggatt (1999), Late Holocene forest disturbance in Gisborne, New Zealand: A comparison of terrestrial and marine pollen records, N. Z. J. Bot., 37, 523-540.

Wilson, C. J. N., and G. P. L. Walker (1985), The Taupo eruption, New Zealand: I. General aspects, Philos. Trans. R. Soc. London, Ser. A, 314, $199-228$

B. Gomez, Geomorphology Laboratory, Indiana State University, Terre Haute, IN 47809, USA.

A. J. Kettner and J. P. M. Syvitski, Environmental Computation and Imaging Group, Institute of Arctic and Alpine Research (INSTAAR), University of Colorado, Boulder, CO 80309-0450, USA. (a.j.kettner@ tudelft.nl) 